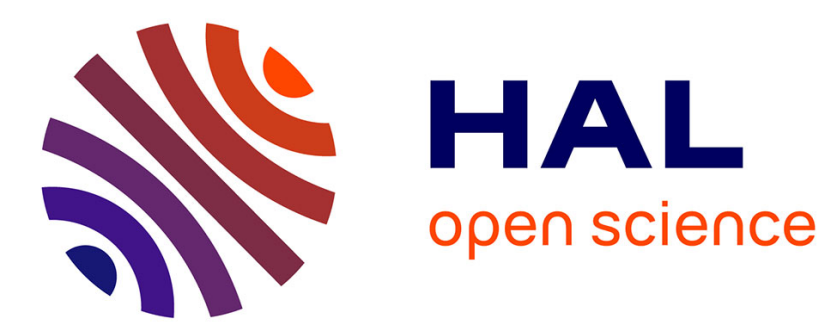

\title{
Selective synthesis of non-symmetrical bis-ureas and their self-assembly
}

Olivier Colombani, Laurent Bouteiller

\section{To cite this version:}

Olivier Colombani, Laurent Bouteiller. Selective synthesis of non-symmetrical bis-ureas and their self-assembly. New Journal of Chemistry, 2004, 28 (11), pp.1373. 10.1039/b316913h . hal-01696746

\section{HAL Id: hal-01696746 https://hal.science/hal-01696746}

Submitted on 18 Sep 2020

HAL is a multi-disciplinary open access archive for the deposit and dissemination of scientific research documents, whether they are published or not. The documents may come from teaching and research institutions in France or abroad, or from public or private research centers.
L'archive ouverte pluridisciplinaire HAL, est destinée au dépôt et à la diffusion de documents scientifiques de niveau recherche, publiés ou non, émanant des établissements d'enseignement et de recherche français ou étrangers, des laboratoires publics ou privés. 


\title{
Selective synthesis of non-symmetrical bis-ureas and their self-assembly
}

\author{
Olivier Colombani ${ }^{a}$, and Laurent Bouteiller ${ }^{a *}$ \\ ${ }^{a}$ Laboratoire de Chimie des Polymères, Tour 44-54, $1^{\text {er }}$ étage, case courrier 185, 4, Place Jussieu, 75252 Paris \\ Cedex 05, Paris, France. Fax: (+33) 1442770 89; Tel: (+33) 1442773 78; E-mail: bouteil@ccr.jussieu.fr
}

\begin{abstract}
Symmetrical bis-ureas composed of two urea functions linked together by a phenyl ring were previously shown to form long supramolecular polymers and thus highly visco-elastic solutions, thanks to a cooperative self-assembly involving four hydrogen bonds. In this paper, we report the direct and selective synthesis of bis-ureas. Mono-isocyanate/mono-ureas were first obtained through a onestep selective reaction between one aromatic amine and one isocyanate function of 2,4-toluene diisocyanate. Then, non-symmetrical bisureas, tetra-ureas, and bis-urea functional polydimethylsiloxanes (PDMS), were obtained by reacting the mono-isocyanate/mono-ureas with well chosen amines. The chloroform solutions of these compounds were characterized by quantitative FTIR spectroscopy and viscosimetry. It was shown that non-symmetrical bis-ureas substituted on one side by an aromatic moiety and on the other by an aliphatic group combine the solubility of aliphatic bis-ureas and the strong association of aromatic ones. Moreover, the association of bis-ureas grafted on polydimethylsiloxanes is efficient and leads to the physical cross-linking of these polymers, even in chloroform.
\end{abstract}

\section{Introduction}

Supramolecular polymers result from the self-assembly of small molecules, which are held together by weak interactions, and lead to polymer-like structures. ${ }^{1-4}$ These systems are increasingly studied because of the reversible character of the process through various stimuli, including temperature, solvent and concentration. Among these systems, we focused on bis-ureas (scheme 1), whose two urea functions are linked together by a rigid spacer. Some of these molecules dissolve spontaneously at room temperature in apolar solvents and lead to visco-elastic solutions at concentrations as low as $1 \%$ by weight. This is due to their selfassembly into long and rigid wires, by four strong cooperative hydrogen bonds. ${ }^{5}$ A range of symmetrical bis-ureas ${ }^{\dagger}$ has previously been synthesized by reacting one equivalent of 2,4toluene diisocyanate $(2,4-\mathrm{TDI})$ with two equivalents of a primary amine. ${ }^{6}$ Up to now, no dissymetrical bis-urea based on 2,4-TDI was obtained.

On the other hand, bis-urea grafted polymers may form selfassembled materials with unique rheological properties, both in bulk and solution. Furthermore, multifunctional compounds such as tetra-ureas can be expected to show an extremely efficient association.

To obtain these new molecules, the selective reaction of an amine with only one isocyanate function of 2,4-TDI, is required (scheme 2 ). The previously cited products may then be obtained by reacting the remaining isocyanate function of the mono-adduct with a well-chosen amino-functional molecule (schemes $3 \mathrm{a}, 3 \mathrm{~b}$, $3 c)$.

According to literature, the ortho isocyanate function of 2,4-TDI is slightly less reactive than the para. ${ }^{7-9}$ Moreover, when one of the two isocyanate is converted to a urea or a urethane function, the reactivity of the remaining isocyanate significantly decreases. $^{9}, 10$ Thus, mono-isocyanate/mono-urethane may be obtained by reacting an alcohol with an excess of 2,4-TDI. ${ }^{10}$ However, amines being more reactive than alcohols, the selectivity of the reaction with isocyanate is expected to decrease. In fact, no detailed selective synthesis of mono-isocyanate/monourea based on 2,4-TDI has been reported yet, even though clues have been given by some authors. ${ }^{8}{ }^{811}$ This paper presents such a selective synthesis with aromatic amines, which are less reactive than aliphatic ones. ${ }^{7}$

\section{Results and Discussion}

\section{1-Synthesis of mono-isocyanate/mono-urea}

\section{Analysis}

The unselective reaction of equimolar amounts of 2,4-TDI and 4$n$ butylaniline $(\mathrm{BuA})$ leads to a mixture of 4 products (scheme 4$)$.
The moisture sensitivity of these products, caused by the remaining isocyanate functions, complicates their analysis. Thus, the product of the first step was reacted with an excess of 2ethylhexylamine (EHA). After this second step, the final mixture is free of isocyanate functions and can be analysed directly by ${ }^{1} \mathrm{H}$ NMR.

The composition of the mixture after the first step can then be deduced from the analysis of the crude product of the second step. Indeed, according to scheme 4, the proportions of (5a), (5b), (1) and (16) in the second step correspond to the amount of (2a), (2b), 2,4-TDI, and (16) respectively in the first step. Moreover, the four bis-ureas potentially obtained at the end of the second step are easily identified by ${ }^{1} \mathrm{H}$ NMR (figures la to $1 \mathrm{~d}$ ) even for proportions of symmetrical bis-ureas as low as $5 \% \mathrm{~mol}$ (figures 1e and 1f). Finally, deconvolution of the 4 peaks, corresponding to the four different bis-ureas, gives an accurate determination of the content of each bis-urea. Thus, the selective formation of mono-isocyanate/mono-urea from 2,4-TDI and $\mathrm{BuA}$ can be accurately and easily evaluated by this two step method.

\section{Influence of solvent and stoechiometry}

The influence of the solvent and of the 2,4-TDI/BuA ratio on the selectivity of the first step was investigated. Three solvents were tested (THF, heptane, dichloromethane) with 2,4-TDI/BuA ratios varying from $1 / 1$ to $5 / 1$ (figure 2). In heptane or dichloromethane, (2) precipitates during the first step, which makes it possible to remove the excess of 2,4-TDI by filtration. In THF however, the mono-isocyanate/mono-ureas are soluble and the excess of 2,4TDI was not removed. The composition of the final product was evaluated for all runs (table 1).

According to table 1 and figure 2, the reaction is not selective in stoechiometric conditions since small amounts of (16) are detected at the end of the second step for OC103, OC134 and OC108. This is caused by the fact that the (2)/2,4-TDI ratio becomes very high at the end of the reaction, and thus the probability for BuA to react with (2) and form (16) becomes significant. ${ }^{10}$

Moreover, several differences are observed when the solvent is changed. First, almost no (1) can be detected when the first step is conducted in heptane or dichloromethane. Indeed, (2) is not soluble in these solvents, unlike 2,4-TDI. Thus, the products of the first step are filtered at the end of the reaction, and the remaining 2,4-TDI is eliminated before adding EHA. On the contrary, (2) is soluble in THF and no purification is done before the second step. The remaining 2,4-TDI yields (1) during the second step.

Furthermore, the selectivity is slightly lower in dichloromethane than in THF or heptane (see the amount of (16) for each run). This observation may be attributed to the formation of a more viscous reaction mixture in dichloromethane than in THF or heptane, due 
to the formation of a thick precipitate. Thus, the poorer selectivity could result from inhomogeneity of the reaction medium.

Finally, the $(\mathbf{5 a}) /(\mathbf{5 b})$ ratio is much above 1 , which confirms the difference of reactivity between the para and ortho isocyanate functions. ${ }^{8}$ This ratio depends on the solvent in the order dichloromethane $>$ heptane $>$ THF. This is probably caused by a difference of solubility between (2b) and (2a) rather than by a difference of reactivity of the two isocyanate functions of 2,4-TDI induced by the solvent. Indeed, (2b) may be more soluble than (2a) and some of it may be eliminated during the filtration in heptane or dichloromethane, but not in THF. This hypothesis is in agreement with the lower yield of the first step in dichloromethane than in heptane.

With an excess of 2,4-TDI, the selectivity of the reaction is improved according to the decreasing amount of (16). Indeed, the excess of 2,4-TDI keeps the (2)/2,4-TDI ratio low throughout the reaction and thus favours the selectivity. Here again, the lower selectivity in dichloromethane is confirmed. Indeed, when 1.5 equivalent of 2,4-TDI is used in the first step, almost no (16) is detected in heptane (OC105) or THF (OC109), whereas a significant proportion is formed in dichloromethane (OC135). Nevertheless, a full selectivity is reached in heptane and dichloromethane with 3 or 5 equivalents of 2,4-TDI (OC116, OC084, OC072). ${ }^{\S}$

In conclusion, the selectivity of the first step is easily reached in either solvent with an excess of 2,4-TDI. Thus, (2) free of (16) can be obtained. Moreover, the use of dichloromethane or heptane is recommended to get rid of the unreacted 2,4-TDI at the end of the reaction. The choice between heptane or dichloromethane depends on the aimed mono-isocyanate/mono-urea. Indeed, heptane should be preferred to obtain (2) (mixture of isomers) in yields higher than $90 \%$, whereas dichloromethane is more indicated to obtain almost pure (2a), but with slightly lower yields $(\sim 70 \%)$.

\section{2-Synthesis of non-symmetrical bis-ureas and bis-urea functional molecules}

Several bis-urea based molecules were synthesized from (2). First, (2), synthesized in dichloromethane and containing low amounts of (2b), was reacted with EHA to obtain almost pure (5a) (scheme $3 \mathrm{a})$. The remaining (5b) was eliminated by recrystallisation in ethyl acetate. It should be highlighted that when (2), containing large amounts of (2b) is used for this reaction, the quantity of (5b) is too large to be eliminated by recrystallisation in ethyl acetate (see supporting information, figure S1). Similarly, aminofunctional polydimethylsiloxanes were transformed into bis-ureafunctional ones (PDMS-g-bis-urea) (scheme 3c). Moreover, tetraureas (i.e. bis-ureas linked together by an aliphatic or a polymeric spacer) were synthesized from diamines and (2) (scheme 3b). The difficult recrystallisation of tetra-ureas containing an aliphatic spacer explains the poor yields of their synthesis. The characteristics of these new compounds are discussed in part 4.

\section{3-Synthesis of other mono-isocyanate/mono-ureas and non- symmetrical bis-ureas}

The synthesis of mono-isocyanate/mono-urea from 2,4-TDI is not limited to the use of BuA. With the analytical technique described above, it was proven that almost pure (3a) is obtained by reacting one equivalent of 2,6-diethylaniline with 5 equivalents of 2,4-TDI in dichloromethane at room temperature (scheme 2). The reaction of this new mono-monoadduct with EHA and recrystallisation of the final product yielded pure (6a) (scheme 3a).

Finally, N-methylaniline, a secondary amine, was used to synthesize a new type of mono-adduct (4) (scheme 2). The synthesis was performed with 5 equivalents of 2,4-TDI in heptane at $0^{\circ} \mathrm{C}$. Then (4) was either reacted with EHA to obtain (7) or with an amino functional PDMS to yield the PDMS-g-bis-urea (15) (schemes $3 \mathrm{a}$ and $3 \mathrm{c}$ ). As the purification of (4) was more difficult than that of the other mono-adducts, a small quantity of 2,4-TDI remained at the end of the first step. Pure (7) was obtained after column chromatography, precipitation, and recrystallisation. The polymer grafted with (4) underwent limited chain extension reactions because of the presence of traces of 2,4-TDI, ${ }^{12}$ but its molecular weight increased only moderately and it was not chemically cross-linked.

\section{4-Characterization in solution}

The solubility of all synthesized molecules was first tested (table 2).

The aliphatic tetra-ureas (8) to (11) are hardly soluble, even in polar solvents such as THF. The presence of branching in the spacer of (10) does not improve the solubility significantly. Consequently, these compounds were not studied further.

The amino-functional PDMS are viscous oils, whereas the bisurea modified PDMS (12) to (15) are rubbery solids. However, this dramatic change of behaviour is only caused by a physical cross-linking of the material. Indeed, the PDMS modified by bisureas are soluble in THF (a solvent of the polymer backbone and a very good hydrogen bond competitor as well), which confirms that they are not chemically cross-linked. On the contrary, (12) and (14), which contain a large amount of bis-urea, swell in heptane, toluene or chloroform, as if they were cross-linked. Indeed, these solvents of the polymer backbone are too weak hydrogen bond competitors to prevent the self-assembly of bisureas into a physical network. As already reported, ${ }^{13}$ the physical cross-linking of PDMS by bis-ureas improves dramatically the tensile properties of these materials.

The properties of solutions of (13) in chloroform are described below.

Finally, (5a) and (7) are very soluble at room temperature. Moreover, (5a) forms a gel in toluene at only $1 \%$ wt. The selfassembly of these molecules was characterized by FTIR spectroscopy and viscosimetry and compared to that of a model symmetrical bis-urea whose properties were already reported: (1) ${ }^{5,6}$ Bis-urea (1) is a good comparative model since it differs from (5a) by only one moiety (schemes 1 and 3a). Compound (6) has a poor solubility and was not studied further.

As already reported, ${ }^{6}$ FTIR spectroscopy in chloroform is a powerful tool to quantify the self-association of bis-ureas. Indeed, the vibration frequency of the $\mathrm{NH}$ function, $v(\mathrm{NH})$, depends on whether it is involved in a hydrogen bond or not: $v$ (bonded $\mathrm{NH})$ $\sim 3350 \mathrm{~cm}^{-1}$, and $v($ free $\mathrm{NH}) \sim 3430 \mathrm{~cm}^{-1}$ (figure 3). The quantitative measurement of these bands provides the fraction of chain ends and thus the length of the supramolecular chains.

The evolution of the fraction of free NH functions was plotted versus bis-urea concentration in chloroform for (5a), (7), and (13) (figure 4). The curves reveal that the self-assembly of bis-ureas increases with their concentration in chloroform, as expected. Moreover, the self-assembly of (1), (5a) and (13) is much stronger than that of a reference mono-urea (N-2-ethylhexyl,N'-2methylphenylurea). This was already reported for (1), ${ }^{6,14}$ and is due to a pre-organization of the urea functions by the toluene spacer. Indeed, when one of the urea functions is hydrogen bonded, the association of the second one is favoured, increasing the overall association strength. Furthermore, the sharp transition between dissociated molecules and almost fully associated ones, observed for the bis-ureas, is characteristic of a strongly cooperative self-assembly. ${ }^{6}$

The comparison of (5a) and (1) shows that the non-symmetrical bis-urea self-assembles much better than the symmetrical one (figure 4). This is certainly caused by the presence of the additional aromatic moiety in (5a), which increases the acidity of the nearest $\mathrm{NH},{ }^{15}, 16$ without hindering too much the association. However, the cooperativity of the association is not significantly affected by the increased strength of the hydrogen bonds. It is worth mentioning that the symmetrical bis-urea with two aromatic substituents (16) should self-assemble even more strongly than 
(5a), but (16) is not soluble in the solvents considered (table 2). This emphasizes the usefulness of non-symmetrical bis-urea (5a), which combines the solubility of aliphatic bis-ureas with the strong association of aromatic ones.

The PDMS tetra-urea (13) begins to associate almost at the same concentration $\left(10^{-4} \mathrm{~mol} / \mathrm{L}\right)$ as $(\mathbf{5 a})$, which is not surprising since these molecules are composed of very similar bis-ureas. Nevertheless, the cooperativity of the self-assembly of (13) is much lower than that of (5a). This may be explained by the bulkiness of the macromolecular chain of (13) which probably hinders the formation of very long supramolecular chains. ${ }^{17}$ Moreover, the fact that bis-ureas are linked pair wise by a macromolecular spacer may add an additional entropic cost to the self-assembly. ${ }^{18}$ However, the self-assembly of bis-ureas grafted on a PDMS chain is still very good.

Finally, the behaviour of the bis-urea with only $3 \mathrm{NH}$ functions (7) is intermediate between the behaviours of the mono-urea and the other bis-ureas.

Beside these qualitative results, a theoretical model can be used to describe the association of bis-ureas (scheme 5). ${ }^{6}$ In this model, $\mathrm{K}_{2}$ represents the equilibrium constant for the association between two free bis-ureas, whereas $\mathrm{K}$ corresponds to the association between a free bis-urea and a supramolecular oligomer containing at least two bis-ureas.

The values of $\mathrm{K}_{2}$ and $\mathrm{K}$ were determined by fitting this theoretical model to the experimental points for (1), (5a), (13), and the monourea (table 3 ). The experimental points were not accurate enough to determine precisely $\mathrm{K}$ and $\mathrm{K}_{2}$ for (7). Thanks to this model, the different bis-ureas can be compared. Indeed, $\mathrm{K} / \mathrm{K}_{2}$ is an evaluation of the cooperativity of the system, whereas $\mathrm{K}^{2} / \mathrm{K}_{2}$ is the association constant between two oligomers and characterizes the strength of the self-assembly. ${ }^{6}$

The values of $\mathrm{K} / \mathrm{K}_{2}$ and $\mathrm{K}^{2} / \mathrm{K}_{2}$ confirm the previous qualitative observations (table 3 ). In particular, $\mathrm{K}^{2} / \mathrm{K}_{2}$ is much lower for the mono-urea than for the bis-ureas. Moreover, the self-assembly of (13) is much less cooperative than that of the low molecular weight compounds (1) and (5a).

As the bis-urea concentration in chloroform increases, the selfassembly leads to larger and larger structures. Thus, the measurement of the resulting increase of viscosity of the solution is a good way to estimate the strength of the self-assembly.

Viscosimetry measurements are reported on figure 5 and show that the viscosity of (5a) is much higher than that of (1) at a given concentration. This difference is in agreement with the much stronger self-assembly of (5a). The PDMS bis-urea (13) is also more viscous than (1) at a given mass concentration in spite of its low bis-urea content. This may be explained first by the bifunctionality of (13), which probably leads to the formation of a reversible network, because each bis-urea function is expected to take part in the formation of a multifunctional supramolecular chain. Moreover, the contribution of the macromolecular backbone of (13) is not negligible as hinted by the evolution of the viscosity of the amino-functional precursor of (13). Thus, (13) possesses very promising rheological properties, even for low bisurea concentrations, thanks to its macromolecular structure and its bifunctionnality.

Finally, the bis-urea with only $3 \mathrm{NH}$ functions (7) forms solutions of very low viscosity. This is shown by monitoring the viscosity of a solution of (1) + (7) in toluene as a function of the ratio of (7), for a constant total concentration (figure 6). This curve shows that the viscosity of the solution decreases rapidly with low amounts of (7). This bis-urea, possessing only $3 \mathrm{NH}$ functions, one of which is sterically hindered, acts as a supramolecular chain stopper.

\section{Conclusion}

The selective reaction of an aromatic amine with an excess of 2,4TDI yielded pure mono-isocyanate/mono-ureas for three different amines. ${ }^{1} \mathrm{H}$ NMR was used to identify the four possible products of the reaction and determine their proportion. With 4$n$ butylaniline as the first amine, the first step is fully selective in dichloromethane or heptane when an appropriate excess of 2,4TDI is used. Moreover the excess of 2,4-TDI can be eliminated easily by filtration. Almost pure (2a) can be obtained in dichloromethane with a yield of about $70 \%$, whereas a (2a)/(2b) mixture $(85 / 15$ molar ratio) is collected with a higher yield $(>90 \%)$ in heptane.

The selective synthesis of these mono-isocyanate/mono-ureas is of great interest since it enables the development of new interesting compounds. First, the non-symmetrical bis-urea (5a) combines the solubility of aliphatic bis-ureas with the strong selfassembly of aromatic ones. Consequently, it self-assembles in chloroform more strongly than (1). On the contrary, (7) selfassembles much less than classical bis-ureas, because one of its $\mathrm{NH}$ functions is missing. Thus, this compound can be used as a supramolecular chain stopper of bis-ureas.

Moreover, liquid amino-functional PDMS are changed into rubbery solids when modified by bis-ureas, thanks to physical cross-linking. ${ }^{13}$ More details on the mechanical properties of these materials will be given shortly. ${ }^{19}$

Furthermore, (13), which consists of two bis-ureas grafted at each end of a PDMS chain, presents very interesting solution properties according to viscosity measurements in chloroform. These properties are related to the very good self-assembly of bis-ureas grafted on this compound in spite of the bulkiness of the PDMS polymeric chain.

\section{Experimental part}

Spectroscopic methods. ${ }^{1} \mathrm{H}$ NMR spectra were recorded on a Brüker AC200C $200 \mathrm{MHz}$ spectrometer at $20^{\circ} \mathrm{C}$. FTIR spectra were obtained with a Nicolet Avatar 320 C spectrometer at $20^{\circ} \mathrm{C}$. Routine spectra were recorded from solutions evaporated on $\mathrm{KBr}$ disks. Quantitative FTIR was done in solution in $\mathrm{KBr}$ cells of 0.1$2.5 \mathrm{~cm}$ path length.

Quantitative FTIR spectroscopy. Mother chloroform solutions were prepared and diluted to reach low concentrations. They were prepared at room temperature, under stirring, for at least one night. After dilution of the mother solutions, daughter solutions were obtained, and stirred for one hour or more. Deuterated chloroform $\left(\mathrm{CDCl}_{3}\right)$ was used instead of hydrogenated chloroform $\left(\mathrm{CHCl}_{3}\right)$ which absorbs too much in the $\mathrm{NH}$ region for diluted solutions.

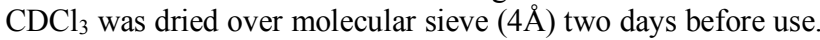
The solutions themselves were not dried because bis-ureas are absorbed on molecular sieve.

Capillary Viscosimetry. Measurements were performed at $25 \pm$ $0.1{ }^{\circ} \mathrm{C}$ with a Cannon-Manning (M108 $\left.\mathrm{n}^{\circ} 25\right)$ semimicro viscometer. Solutions in chloroform (stabilized with amylenes) were filtered on a Millex PVDF filter $(0.45 \mu \mathrm{m})$ before viscosity measurements, whereas toluene solutions were not filtered because of their high viscosity. No significant difference were observed when $\mathrm{CDCl}_{3}$ was used instead of $\mathrm{CHCl}_{3}{ }^{6}$ The toluene mother solution of (1) was prepared one week before use and heated one day at $50^{\circ} \mathrm{C}$ to improve its homogeneity. The toluene mother solution of (7) was prepared one day before use at room temperature. Solutions of (1) and (7) at the same weight concentration were mixed to obtain the daughter solutions at different (1)/(7) ratios and constant concentration.

Synthesis. Analytical grade solvents were used and could be dried by refluxing over calcium hydride (dichloromethane, chloroform), or sodium (THF, heptane, toluene, dioxane) for several hours and then distilling. 
2,4-toluene diisocyanate (96\% 2,4-TDI + 4\% 2,6-TDI), 2ethylhexylamine $(98 \%)$, 2-butyl-2-ethyl-1,5-diaminopentane (98\%), and 1,10-diaminodecane (97\%), from Aldrich, as well as AMS-162, from ABCR, were used as received. 4- $n$ butylaniline (97\%), 2,6-diethylaniline (98\%), N-methylaniline (98\%), 1,2diaminoethane (99\%), and 1,3-diaminopropane (99\%), were purchased from Aldrich, and distilled before use. The synthesis of (1) was previously reported.

Mono-isocyanate/mono-urea (2). A solution of BuA (13.2mL, $0.084 \mathrm{~mol})$ in dry dichloromethane $(400 \mathrm{~mL})$ was added in 8 hours, at room temperature and under nitrogen, to a stirred solution of $2,4-$ TDI $(60 \mathrm{~mL}, 0.419 \mathrm{~mol})$ in dry dichloromethane $(400 \mathrm{~mL})$. The reaction mixture was stirred overnight. The white precipitate formed was then quickly filtered on a fritted funnel, rinsed three times with dry dichloromethane $(3 * 50 \mathrm{~mL})$, and dried under vacuum to afford $19.7 \mathrm{~g}$ of a white solid $(73 \%)$. No further purification was done because of the moisture sensitivity of the product. The purity of the product was checked by ${ }^{1} \mathrm{H}$ NMR and by the two step method described in part 1.1. ${ }^{1} \mathrm{H}$ NMR $(200 \mathrm{MHz}$, $\left[\mathrm{D}_{6}\right] \mathrm{DMSO}$ dried over molecular sieve, $\left.22^{\circ} \mathrm{C}\right)$ : $\delta(\mathrm{ppm})=8.73 / 8.64(\mathrm{~s}, \quad 2 \mathrm{H}, \quad \operatorname{Ar}-\mathrm{N} H), \quad \delta=7.42(\mathrm{~s}, \quad 1 \mathrm{H}, \quad \operatorname{Ar}-H)$, $\delta=7.34 / 7.12\left(\mathrm{~d},{ }^{3} \mathrm{~J}(\mathrm{H}, \mathrm{H})=8 \mathrm{~Hz}, 4 \mathrm{H}, \mathrm{Ar}-H\right), \delta=7.13 / 7.06(\mathrm{~s}, 2 \mathrm{H}, \mathrm{Ar}-$ $H), \delta=2.5\left(\mathrm{t}, 2 \mathrm{H}, \mathrm{Ar}-\mathrm{CH}_{2}\right), \delta=2.22\left(\mathrm{~s}, 3 \mathrm{H}, \mathrm{Ar}-\mathrm{CH}_{3}\right), \delta=1.52(\mathrm{~m}, 2 \mathrm{H}$, $\left.\mathrm{Ar}-\mathrm{CH}_{2}-\mathrm{CH}_{2}\right), \quad \delta=1.31\left(\mathrm{~m}, 2 \mathrm{H}, \quad \mathrm{Ar}-\mathrm{CH}_{2}-\mathrm{CH}_{2}-\mathrm{CH}_{2}\right), \quad \delta=0.88(\mathrm{t}$, $\left.{ }^{3} \mathrm{~J}(\mathrm{H}, \mathrm{H})=7 \mathrm{~Hz}, 3 \mathrm{H}, \mathrm{CH}_{3}\right)$.

When the reaction is performed in dry heptane, the experimental conditions are the same. No purification is done when the reaction is conducted in dry THF. The 2,4-TDI/BuA ratio is adapted for each run, but the concentration of each reagent is unchanged.

Mono-isocyanate/mono-urea (3). The reaction procedure is identical to that of (2) and conducted at room temperature in dry dichloromethane. A white solid $(89 \%)$ is collected by filtration. ${ }^{1} \mathrm{H}$ NMR $\left(200 \mathrm{MHz},\left[\mathrm{D}_{6}\right] \mathrm{DMSO}\right.$ dried over molecular sieve, $\left.22^{\circ} \mathrm{C}\right): \delta(\mathrm{ppm})=8.88 / 7.76(\mathrm{~s}, 2 \mathrm{H}, \operatorname{Ar}-\mathrm{N} H), \delta=7.42(\mathrm{~s}, 1 \mathrm{H}, \mathrm{Ar}-H)$, $\delta=7.13(\mathrm{~m}, 5 \mathrm{H}, \operatorname{Ar}-H), \delta=2.54\left(\mathrm{q},{ }^{3} \mathrm{~J}(\mathrm{H}, \mathrm{H})=7 \mathrm{~Hz}, 4 \mathrm{H}, \operatorname{Ar}-\mathrm{CH}_{2}\right)$, $\delta=2.21\left(\mathrm{~s}, 3 \mathrm{H}, \mathrm{Ar}-\mathrm{CH}_{3}\right), \delta=1.12\left(\mathrm{t},{ }^{3} \mathrm{~J}(\mathrm{H}, \mathrm{H})=7 \mathrm{~Hz}, 6 \mathrm{H}, \mathrm{Ar}-\mathrm{CH}_{2-}\right.$ $\left.\mathrm{CH}_{3}\right)$.

Mono-isocyanate/mono-urea (4). A solution of N-methylaniline $(6.0 \mathrm{~mL}, 0.056 \mathrm{~mol})$ in dry heptane $(200 \mathrm{~mL})$ was added in $2 \mathrm{~h} 30$, at $0^{\circ} \mathrm{C}$ and under nitrogen, to a stirred solution of 2,4-TDI $(40 \mathrm{~mL}$, $0.279 \mathrm{~mol})$ in dry heptane $(270 \mathrm{~mL})$. The reaction mixture was stirred for several hours at $0^{\circ} \mathrm{C}$ and allowed to warm up to room temperature overnight. The white precipitate formed was then quickly filtered on a fritted funnel, rinsed with dry heptane $(3 * 50 \mathrm{~mL})$, and dried under vacuum to afford $10.1 \mathrm{~g}$ of a white solid (64\%). No further purification was performed because of the moisture sensitivity of the product. The purity of the product was only checked by the two step ${ }^{1} \mathrm{H}$ NMR method described in part 1.1 .

Non-symmetrical bis-ureas - evaluation of the purity of the monoisocyanate/mono-urea. Pure EHA $\left(0.27 \mathrm{~mL}, 1.6 .10^{-3} \mathrm{~mol}\right)$ was added to a stirred solution of (2) $\left(0.5 \mathrm{~g}, 1.5 .10^{-3} \mathrm{~mol}\right.$ of monoisocyanate/mono-urea expected) in dry THF $(20 \mathrm{~mL})$ in order to convert the remaining isocyanate functions of this product. After one night, the end of the reaction was checked by the absence of isocyanate band by FTIR $\left(2270 \mathrm{~cm}^{-1}\right)$ and the crude product was collected after elimination of the solvent. ${ }^{1} \mathrm{H}$ NMR of this crude product was realised in order to identify the bis-ureas it contains and deduce the selectivity of the first step. ${ }^{1} \mathrm{H}$ NMR $(200 \mathrm{MHz}$, $\left.\left[\mathrm{D}_{6}\right] \mathrm{DMSO}, 22^{\circ} \mathrm{C}\right)$ between 1.1 and $2.6 \mathrm{ppm}: \delta(\mathrm{ppm})=2.5(\mathrm{t}, 2 \mathrm{H}$, $\mathrm{Ar}-\mathrm{CH}_{2}-$ and DMSO), $\delta=2.18\left(\mathrm{~s}, 3 \mathrm{H}, \mathrm{Ar}_{-} \mathrm{CH}_{3}\right.$ of (16)),$\delta=2.15(\mathrm{~s}$, $3 \mathrm{H}, \mathrm{Ar}-\mathrm{CH}_{3}$ of (5b)), $\delta=2.11\left(\mathrm{~s}, 3 \mathrm{H}, \mathrm{Ar}-\mathrm{CH}_{3}\right.$ of (5a)), $\delta=2.08(\mathrm{~s}$, $3 \mathrm{H}, \mathrm{Ar}-\mathrm{CH}_{3}$ of (1)), $\delta=1.52\left(\mathrm{~m}, 2 \mathrm{H}, \mathrm{Ar}-\mathrm{CH}_{2}-\mathrm{CH}_{2}\right), \delta=1.27(\mathrm{~m}$, $\left.11 \mathrm{H}, \mathrm{CH} / \mathrm{CH}_{2} / \mathrm{Ar}-\mathrm{CH}_{2}-\mathrm{CH}_{2}-\mathrm{CH}_{2}\right)$.
Non-symmetrical bis-urea (5a). A solution of EHA $(1.06 \mathrm{~mL}$, $\left.6.5 .10^{-3} \mathrm{~mol}\right)$ in dry dioxane $(20 \mathrm{~mL})$ was added in $10 \mathrm{~min}$, at room temperature and under nitrogen, to a stirred solution of (2) (run OC072: dichloromethane, 2,4-TDI/BuA $=5 / 1-2.0 \mathrm{~g}, 6,2.10^{-3}$ mol) in dry dioxane $(150 \mathrm{~mL})$. A white precipitate appeared rapidly. After one night of stirring, the precipitate was filtered on a fritted funnel, rinsed three times with small quantities of dry dioxane, and dried under vacuum to afford $2.1 \mathrm{~g}$ of a white solid. The product was then recrystallised in ethyl acetate (final yield $=$ $56 \%)$ to get rid of the remaining (5b). ${ }^{1} \mathrm{H}$ NMR $(200 \mathrm{MHz}$, $\left.\left[\mathrm{D}_{6}\right] \mathrm{DMSO}, 22^{\circ} \mathrm{C}\right): \delta(\mathrm{ppm})=8.55 / 8.38(\mathrm{~s}, 2 \mathrm{H}, \mathrm{Ar}-\mathrm{N} H), \delta=7.87(\mathrm{~d}$, $\left.{ }^{4} \mathrm{~J}(\mathrm{H}, \mathrm{H})=2 \mathrm{~Hz}, 1 \mathrm{H}, \quad \operatorname{Ar}-H\right), \delta=7.54(\mathrm{~s}, 1 \mathrm{H}, \operatorname{Ar}-\mathrm{N} H), \delta=7.32(\mathrm{~d}$, $\left.{ }^{3} \mathrm{~J}(\mathrm{H}, \mathrm{H})=8 \mathrm{~Hz}, \quad 2 \mathrm{H}, \quad \operatorname{Ar}-H\right), \quad \delta=7.16\left(\mathrm{dd}, \quad{ }^{3} \mathrm{~J}(\mathrm{H}, \mathrm{H})=8 \mathrm{~Hz}\right.$, $\left.{ }^{4} \mathrm{~J}(\mathrm{H}, \mathrm{H})=2 \mathrm{~Hz}, 1 \mathrm{H}, \mathrm{Ar}-H\right), \delta=7.07 / 6,97\left(\mathrm{~d},{ }^{3} \mathrm{~J}(\mathrm{H}, \mathrm{H})=8 \mathrm{~Hz}, 3 \mathrm{H}, \mathrm{Ar}-\right.$ $H), \delta=6.53\left(\mathrm{t},{ }^{3} \mathrm{~J}(\mathrm{H}, \mathrm{H})=6 \mathrm{~Hz}, 1 \mathrm{H}, \mathrm{CH}_{2}-\mathrm{N} H\right), \delta=3.06(\mathrm{~m}, 2 \mathrm{H}, \mathrm{N}-$ $\left.\mathrm{CH}_{2}\right), \delta=2.5\left(\mathrm{t}, 2 \mathrm{H}, \mathrm{Ar}-\mathrm{CH}_{2}\right), \delta=2.11\left(\mathrm{~s}, 3 \mathrm{H}, \mathrm{Ar}-\mathrm{CH}_{3}\right), \delta=1.52(\mathrm{~m}$,

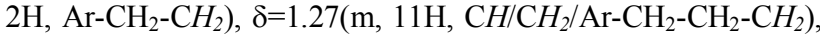
$\delta=0.88\left(\mathrm{t}, \quad{ }^{3} \mathrm{~J}(\mathrm{H}, \mathrm{H})=7 \mathrm{~Hz}, \quad 9 \mathrm{H}, \quad \mathrm{CH}_{3}\right) ;{ }^{13} \mathrm{C}-\mathrm{NMR} \quad(50 \mathrm{MHz}$, $\left.\left[\mathrm{D}_{6}\right] \mathrm{DMSO}, \quad 22^{\circ} \mathrm{C}\right): \quad \delta(\mathrm{ppm})=155.5 / 152.6(\mathrm{C}=\mathrm{O})$, $\delta=138.6 / 137.9 / 137.5 / 135.5 / 130.1 /$

$128.5 / 119.2 / 118.1 / 111.4 / 109.9 \quad(A r), \quad \delta=41.5\left(\mathrm{~N}-C_{2}\right), \quad \delta=39.8$ $(\mathrm{CH}), \quad \delta=34.3 / 33.4 / 30.6 / 28.6 / 23.8 / 22.6 / 21.8\left(\mathrm{CH}_{2}\right), \quad \delta=17.3(\mathrm{Ar}-$ $\left.\mathrm{CH}_{3}\right), \delta=14.0 / 13.8 / 10.9\left(\mathrm{CH}_{3}\right) ; \mathrm{IR}(\mathrm{KBr}): \mathrm{v}=3333 / 3281 \mathrm{~cm}^{-1}(\mathrm{~N}-\mathrm{H})$, $\nu=1641 \mathrm{~cm}^{-1}(\mathrm{C}=\mathrm{O})$; elemental analysis calcd $(\%)$ for $\mathrm{C}_{27} \mathrm{H}_{40} \mathrm{~N}_{4} \mathrm{O}_{2}$ (452.6): C 71.65, H 8.91, N 12.38, O 7.07; found: C 71.22, H 8.98, $\mathrm{N} 12.29$, O 7.62. (5a) contains a little water ( $1 \%$ by weight $)$ which increases the percentage of $\mathrm{O}$ compared to $\mathrm{C}$ and $\mathrm{N}$.

Non-symmetrical bis-urea (6). The synthesis is derived from that of (5a) except that the reaction was conducted in dry chloroform and with the mono-isocyanate/mono-urea (3) at a concentration of $2.3 \mathrm{~g} / \mathrm{L}$. At the end of the reaction, the precipitate was too thin to be filtered. After the elimination of most of the solvent, the product was precipitated in heptane, filtered, washed thoroughly with heptane, dried under vacuum, and recrystallised in ethanol (yield $=63 \%) .{ }^{1} \mathrm{H}$ NMR $\left(200 \mathrm{MHz},\left[\mathrm{D}_{6}\right] \mathrm{DMSO}, 22^{\circ} \mathrm{C}\right)$ : $\delta(\mathrm{ppm})=8.62(\mathrm{~s}, 1 \mathrm{H}, \operatorname{Ar}-\mathrm{N} H), \delta=7.83\left(\mathrm{~d},{ }^{4} \mathrm{~J}(\mathrm{H}, \mathrm{H})=2 \mathrm{~Hz}, 1 \mathrm{H}, \mathrm{Ar}-H\right)$, $\delta=7.53 / 7.47(\mathrm{~s}, \quad 2 \mathrm{H}, \quad \operatorname{Ar}-\mathrm{N} H), \quad \delta=7.17\left(\mathrm{dd}, \quad{ }^{3} \mathrm{~J}(\mathrm{H}, \mathrm{H})=8 \mathrm{~Hz}\right.$, $\left.{ }^{4} \mathrm{~J}(\mathrm{H}, \mathrm{H})=2 \mathrm{~Hz}, 1 \mathrm{H}, \operatorname{Ar}-H\right), \delta=7.10(\mathrm{~m}, 3 \mathrm{H}, \operatorname{Ar}-H), \delta=6.95(\mathrm{~d}$, $\left.{ }^{3} \mathrm{~J}(\mathrm{H}, \mathrm{H})=8 \mathrm{~Hz}, 1 \mathrm{H}, \mathrm{Ar}-H\right), \delta=6.50\left(\mathrm{t},{ }^{3} \mathrm{~J}(\mathrm{H}, \mathrm{H})=6 \mathrm{~Hz}, 1 \mathrm{H}, \mathrm{CH}_{2}-\mathrm{N} H\right)$, $\delta=3.06\left(\mathrm{~m}, 2 \mathrm{H}, \mathrm{N}-\mathrm{CH}_{2}\right), \delta=2.59\left(\mathrm{q},{ }^{3} \mathrm{~J}(\mathrm{H}, \mathrm{H})=7 \mathrm{~Hz}, 4 \mathrm{H}, \mathrm{Ar}-\mathrm{CH}_{2}\right)$, $\delta=2.10\left(\mathrm{~s}, 3 \mathrm{H}, \mathrm{Ar}-\mathrm{CH}_{3}\right), \delta=1.27\left(\mathrm{~m}, 9 \mathrm{H}, \mathrm{CH} / \mathrm{CH}_{2}\right), \delta=1.13(\mathrm{t}$, $\left.{ }^{3} \mathrm{~J}(\mathrm{H}, \mathrm{H})=7 \mathrm{~Hz}, 6 \mathrm{H}, \mathrm{Ar}-\mathrm{CH}_{2}-\mathrm{CH}_{3}\right), \delta=0.88\left(\mathrm{~m}, 6 \mathrm{H}, \mathrm{CH}_{3}\right)$; elemental analysis calcd (\%) for $\mathrm{C}_{27} \mathrm{H}_{40} \mathrm{~N}_{4} \mathrm{O}_{2}$ (452.6): $\mathrm{C} 71.65, \mathrm{H}$ 8.91, N 12.38, O 7.07; found: $\mathrm{C} 71.40, \mathrm{H} 8.97, \mathrm{~N} \mathrm{12.32,} \mathrm{O} \mathrm{7.70.} \mathrm{(6)}$ contains a little water $(\sim 1 \%$ by weight $)$ which increases the percentage of $\mathrm{O}$ compared to $\mathrm{C}$ and $\mathrm{N}$.

Non-symmetrical bis-urea (7). The synthesis is derived from that of (5a), except that the mono-isocyanate/mono-urea used was (4) and that the reaction was conducted in dry THF. The crude product was collected by evaporation of the solvent, and then purified by silica gel column chromatography with chloroform/ethanol $(96 / 4 \mathrm{v} / \mathrm{v})$ as the eluent, precipitated from a concentrated chloroform solution in heptane, and recrystallised in an heptane/cyclohexane (78/22 v/v) mixture. A white product was obtained with a final yield of $11 \% .{ }^{1} \mathrm{H}$ NMR $(200 \mathrm{MHz}$, $\left.\left[\mathrm{D}_{6}\right] \mathrm{DMSO}, 22^{\circ} \mathrm{C}\right): \delta(\mathrm{ppm})=7.97(\mathrm{~s}, 1 \mathrm{H}, \quad \mathrm{Ar}-\mathrm{N} H), \delta=7.79(\mathrm{~d}$, $\left.{ }^{4} \mathrm{~J}(\mathrm{H}, \mathrm{H})=2 \mathrm{~Hz}, 1 \mathrm{H}, \operatorname{Ar}-H\right), \delta=7.50(\mathrm{~s}, 1 \mathrm{H}, \operatorname{Ar}-\mathrm{N} H), \delta=7.32(\mathrm{~m}, 5 \mathrm{H}$, $\operatorname{Ar}-H), \quad \delta=7.07\left(\mathrm{dd}, \quad{ }^{3} \mathrm{~J}(\mathrm{H}, \mathrm{H})=8 \mathrm{~Hz},{ }^{4} \mathrm{~J}(\mathrm{H}, \mathrm{H})=2 \mathrm{~Hz}, \quad 1 \mathrm{H}, \quad \operatorname{Ar}-H\right)$, $\delta=6.94\left(\mathrm{~d},{ }^{3} \mathrm{~J}(\mathrm{H}, \mathrm{H})=8 \mathrm{~Hz}, 1 \mathrm{H}, \operatorname{Ar}-H\right), \delta=6.47\left(\mathrm{t},{ }^{3} \mathrm{~J}(\mathrm{H}, \mathrm{H})=6 \mathrm{~Hz}, 1 \mathrm{H}\right.$, $\left.\mathrm{CH}_{2}-\mathrm{NH}\right), \delta=3.25\left(\mathrm{~s}, 3 \mathrm{H}, \quad \mathrm{N}-\mathrm{CH}_{3}\right), \delta=3.03\left(\mathrm{~m}, 2 \mathrm{H}, \mathrm{N}-\mathrm{CH}_{2}\right)$, $\delta=2.10\left(\mathrm{~s}, 3 \mathrm{H}, \mathrm{Ar}-\mathrm{CH}_{3}\right), \delta=1.25\left(\mathrm{~m}, 9 \mathrm{H}, \mathrm{CH} / \mathrm{CH}_{2}\right), \delta=0.86(\mathrm{~m}, 6 \mathrm{H}$, $\left.\mathrm{CH}_{3}\right) .{ }^{13} \mathrm{C} \quad \mathrm{NMR} \quad\left(50 \mathrm{MHz}, \quad\left[\mathrm{D}_{6}\right] \mathrm{DMSO},{ }_{22}^{\circ} \mathrm{C}\right)$ : $\delta(\mathrm{ppm})=155.3 / 154.8(C=\mathrm{O}), \quad \delta=144.3 / 138.0 / 129.4 / 129.2 / 126.2 /$ $125.6 / 120.3 / 113.9 / 112.6(A r), \quad \delta=41.6\left(\mathrm{~N}-C_{2}\right), \quad \delta=39.3(C H)$, $\delta=37.4\left(\mathrm{~N}-\mathrm{CH}_{3}\right), \delta=30.5 / 28.5 / 23.7 / 22.5\left(\mathrm{CH}_{2}\right), \delta=17.3\left(\mathrm{Ar}-\mathrm{CH}_{3}\right)$, $\delta=14.0 / 10.8\left(\mathrm{CH}_{3}\right)$; elemental analysis calcd $(\%)$ for $\mathrm{C}_{24} \mathrm{H}_{34} \mathrm{~N}_{4} \mathrm{O}_{2}$ (410.6): C 70.21, H 8.35, N 13.65, O 7.79; found: C 69.82, H 8.35, $\mathrm{N} 14.05, \mathrm{O} 8.03$. 
Tetra-urea (11). A solution of 1,10-diaminodecane $(1.20 \mathrm{~g}$, $\left.6.98 .10^{-3} \mathrm{~mol}\right)$ in dry THF $(240 \mathrm{~mL})$ was slowly added, at room temperature and under nitrogen, to a stirred solution of (2) (run OC084: heptane, 2,4-TDI/BuA ratio $=5 / 1-4.51 \mathrm{~g}, 13.95 .10^{-3}$ mol) in dry THF $(180 \mathrm{~mL})$. An off-white solid precipitated quickly. After one night, FTIR spectroscopy revealed the absence of remaining isocyanate functions $\left(2270 \mathrm{~cm}^{-1}\right)$. The precipitate was then filtered on a Buchner, rinsed with THF and dried under vacuum. $5.4 \mathrm{~g}$ of a yellowish solid was obtained. The recrystallization of this crude product in $\mathrm{DMF}$ at $80^{\circ} \mathrm{C}$ lead to a white product $(17 \%) .{ }^{1} \mathrm{H}$ NMR $\left(200 \mathrm{MHz},\left[\mathrm{D}_{6}\right] \mathrm{DMSO}, 22^{\circ} \mathrm{C}\right)$ : $\delta(\mathrm{ppm})=8.52 / 8.38(\mathrm{~s}, 4 \mathrm{H}, \mathrm{Ar}-\mathrm{N} H), \delta=7.85(\mathrm{~s}, 2 \mathrm{H}, \mathrm{Ar}-H), \delta=7.50(\mathrm{~s}$, $2 \mathrm{H}, \operatorname{Ar}-\mathrm{N} H), \delta=7.32\left(\mathrm{~d},{ }^{3} \mathrm{~J}(\mathrm{H}, \mathrm{H})=8 \mathrm{~Hz}, 4 \mathrm{H}, \operatorname{Ar}-H\right), \delta=7.11(\mathrm{dd}$, $\left.{ }^{3} \mathrm{~J}(\mathrm{H}, \mathrm{H})=8 \mathrm{~Hz}, \quad{ }^{4} \mathrm{~J}(\mathrm{H}, \mathrm{H})=2 \mathrm{~Hz}, \quad 2 \mathrm{H}, \quad \operatorname{Ar}-H\right), \quad \delta=7.07 / 6,97(\mathrm{~d}$, $\left.{ }^{3} \mathrm{~J}(\mathrm{H}, \mathrm{H})=8 \mathrm{~Hz}, 6 \mathrm{H}, \mathrm{Ar}-H\right), \delta=6.53\left(\mathrm{~m}, 2 \mathrm{H}, \mathrm{CH}_{2}-\mathrm{N} H\right), \delta=3.1(\mathrm{~m}, 4 \mathrm{H}$, $\left.\mathrm{N}-\mathrm{CH}_{2}\right), \delta=2.5\left(\mathrm{t}, 4 \mathrm{H}, \mathrm{Ar}-\mathrm{CH}_{2}\right), \delta=2.10\left(\mathrm{~s}, 6 \mathrm{H}, \mathrm{Ar}-\mathrm{CH}_{3}\right), \delta=1.48(\mathrm{~m}$, $\left.4 \mathrm{H}, \quad \mathrm{Ar}-\mathrm{CH}_{2}-\mathrm{CH}_{2}\right), \delta=1.29\left(\mathrm{~m}, 20 \mathrm{H}, \quad \mathrm{CH}_{2} / \mathrm{Ar}-\mathrm{CH}_{2}-\mathrm{CH}_{2}-\mathrm{CH}_{2}\right)$, $\delta=0.88\left(\mathrm{t},{ }^{3} \mathrm{~J}(\mathrm{H}, \mathrm{H})=7 \mathrm{~Hz}, 6 \mathrm{H}, \mathrm{CH}_{3}\right)$; elemental analysis calcd $(\%)$ for $\mathrm{C}_{48} \mathrm{H}_{66} \mathrm{~N}_{8} \mathrm{O}_{4}$ (819.1): C 70.38, H 8.12, N 13.68, O 7.81; found: $\mathrm{C} 70.01, \mathrm{H} 8.20, \mathrm{~N} 13.61, \mathrm{O} 8.54$. (11) contains a little water $(\sim 1 \%$ by weight) which increases the percentage of $\mathrm{O}$ compared to $\mathrm{C}$ and $\mathrm{N}$.

Tetra-ureas $(\mathbf{8 , 9 , 1 0 )}$. The synthesis of these tetra-ureas is derived from that of (11). (8) was recrystallised in DMF/AcOEt $(50 / 50$ $\mathrm{v} / \mathrm{v})$ at $80^{\circ} \mathrm{C}$ (yield $=10 \%$ ). No ${ }^{1} \mathrm{H}$ NMR was done because of the poor solubility of this product. Elemental analysis calcd (\%) for $\mathrm{C}_{40} \mathrm{H}_{50} \mathrm{~N}_{8} \mathrm{O}_{4}$ (706.9): C 67.96, H 7.13, N 15.85, O 9.05; found: $\mathrm{C}$ 67.41, H 7.08, N 16.08, O 9.44.

(9) was recrystallised in DMF/AcOEt $(50 / 50 \mathrm{v} / \mathrm{v})$ at $80^{\circ} \mathrm{C}(10 \%)$. ${ }^{1} \mathrm{H}$ NMR $\left(200 \mathrm{MHz},\left[\mathrm{D}_{6}\right] \mathrm{DMSO}, 22^{\circ} \mathrm{C}\right): \delta(\mathrm{ppm})=8.51 / 8.39(\mathrm{~s}, 4 \mathrm{H}$, $\operatorname{Ar}-\mathrm{N} H), \delta=7.85\left(\mathrm{~d},{ }^{4} \mathrm{~J}(\mathrm{H}, \mathrm{H})=2 \mathrm{~Hz}, 2 \mathrm{H}, \operatorname{Ar}-H\right), \delta=7.61(\mathrm{~s}, 2 \mathrm{H}, \mathrm{Ar}-$ $\mathrm{N} H), \quad \delta=7.32(\mathrm{~d}, \quad 3 \mathrm{~J}(\mathrm{H}, \mathrm{H})=8 \mathrm{~Hz}, \quad 4 \mathrm{H}, \quad \operatorname{Ar}-H), \quad \delta=7.14(\mathrm{dd}$, $\left.{ }^{3} \mathrm{~J}(\mathrm{H}, \mathrm{H})=8 \mathrm{~Hz}, \quad{ }^{4} \mathrm{~J}(\mathrm{H}, \mathrm{H})=2 \mathrm{~Hz}, \quad 2 \mathrm{H}, \quad \operatorname{Ar}-H\right), \quad \delta=7.07 / 6,98(\mathrm{~d}$, $\left.{ }^{3} \mathrm{~J}(\mathrm{H}, \mathrm{H})=8 \mathrm{~Hz}, 6 \mathrm{H}, \mathrm{Ar}-H\right), \delta=6.61\left(\mathrm{t},{ }^{3} \mathrm{~J}(\mathrm{H}, \mathrm{H})=6 \mathrm{~Hz}, 2 \mathrm{H}, \mathrm{CH}_{2}-\mathrm{NH}\right)$, $\delta=3.16\left(\mathrm{~m}, 4 \mathrm{H}, \mathrm{N}-\mathrm{CH}_{2}\right), \delta=2.5\left(\mathrm{t}, 4 \mathrm{H}, \mathrm{Ar}-\mathrm{CH}_{2}\right), \delta=2.12(\mathrm{~s}, 6 \mathrm{H}, \mathrm{Ar}-$ $\left.\mathrm{CH}_{3}\right), \delta=1.59\left(\mathrm{~m}, 2 \mathrm{H}, \mathrm{CH}_{2}-\mathrm{CH}_{2}-\mathrm{CH}_{2}\right), \delta=1.48\left(\mathrm{~m}, 4 \mathrm{H}, \mathrm{Ar}-\mathrm{CH}_{2-}\right.$ $\left.\mathrm{CH}_{2}\right), \delta=1.31\left(\mathrm{~m}, 4 \mathrm{H}, \mathrm{Ar}-\mathrm{CH}_{2}-\mathrm{CH}_{2}-\mathrm{CH}_{2}\right), \delta=0.88\left(\mathrm{t},{ }^{3} \mathrm{~J}(\mathrm{H}, \mathrm{H})=7 \mathrm{~Hz}\right.$, $\left.6 \mathrm{H}, \mathrm{CH}_{3}\right)$; elemental analysis calcd $(\%)$ for $\mathrm{C}_{41} \mathrm{H}_{52} \mathrm{~N}_{8} \mathrm{O}_{4}(720.9)$ : C 68.31, H 7.27, N 15.54, O 8.88; found: C 67.83, H 7.08, N 15.44, O 9.07 .

(10) was collected by evaporation of the THF instead of filtration because the precipitate was too thin to be filtered. Moreover, the reaction lasted for one week instead of one night. It was recrystallised in $\mathrm{DMF} / \mathrm{AcOEt}(17 / 83 \mathrm{v} / \mathrm{v})$ at $80^{\circ} \mathrm{C}(21 \%) .{ }^{1} \mathrm{H} \mathrm{NMR}$ $\left(200 \mathrm{MHz},\left[\mathrm{D}_{6}\right] \mathrm{DMSO}, 22^{\circ} \mathrm{C}\right): \delta(\mathrm{ppm})=8.51 / 8.37(\mathrm{~s}, 4 \mathrm{H}, \mathrm{Ar}-\mathrm{N} H)$, $\delta=7.86 / 7.83\left(\mathrm{~d},{ }^{4} \mathrm{~J}(\mathrm{H}, \mathrm{H})=2 \mathrm{~Hz}, 2 \mathrm{H}, \mathrm{Ar}-H\right), \delta=7.62 / 7.52(\mathrm{~s}, 2 \mathrm{H}, \mathrm{Ar}-$ $\mathrm{N} H), \delta=7.32\left(\mathrm{~d}, \quad{ }^{3} \mathrm{~J}(\mathrm{H}, \mathrm{H})=8 \mathrm{~Hz}, \quad 4 \mathrm{H}, \quad\right.$ Ar $\left.-H\right), \quad \delta=7.18 / 7.15(\mathrm{dd}$, $\left.{ }^{3} \mathrm{~J}(\mathrm{H}, \mathrm{H})=8 \mathrm{~Hz}, \quad{ }^{4} \mathrm{~J}(\mathrm{H}, \mathrm{H})=2.0 \mathrm{~Hz}, \quad 2 \mathrm{H}, \quad \operatorname{Ar}-H\right), \quad \delta=7.06 / 6.98(\mathrm{~d}$, $\left.{ }^{3} \mathrm{~J}(\mathrm{H}, \mathrm{H})=8 \mathrm{~Hz}, 6 \mathrm{H}, \mathrm{Ar}-H\right), \delta=6.58 / 6.40\left(\mathrm{t},{ }^{3} \mathrm{~J}(\mathrm{H}, \mathrm{H})=6 \mathrm{~Hz}, 2 \mathrm{H}, \mathrm{CH}_{2}-\right.$ $\mathrm{NH}), \delta=3.07 / 3.00\left(\mathrm{~m}, 4 \mathrm{H}, \quad \mathrm{N}-\mathrm{CH}_{2}\right), \delta=2.5\left(\mathrm{t}, 4 \mathrm{H}, \quad \mathrm{Ar}-\mathrm{CH}_{2}\right)$, $\delta=2.13 / 2.10\left(\mathrm{~s}, \quad 6 \mathrm{H}, \quad \mathrm{Ar}-\mathrm{CH}_{3}\right), \quad \delta=1.55\left(\mathrm{~m}, 4 \mathrm{H}, \mathrm{Ar}-\mathrm{CH}_{2}-\mathrm{CH}_{2}\right)$, $\delta=1.31\left(\mathrm{~m}, \quad 16 \mathrm{H}, \quad \mathrm{CH} / \mathrm{Ar}-\mathrm{CH}_{2}-\mathrm{CH}_{2}-\mathrm{CH}_{2}\right), \quad \delta=0.88 / 0.80(\mathrm{t}$, $\left.{ }^{3} \mathrm{~J}(\mathrm{H}, \mathrm{H})=7 \mathrm{~Hz}, 12 \mathrm{H}, \mathrm{CH}_{3}\right)$; elemental analysis calcd $(\%)$ for $\mathrm{C}_{49} \mathrm{H}_{68} \mathrm{~N}_{8} \mathrm{O}_{4}$ (833.1): C 70.64, H 8.23, N 13.45, O 7.68; found: $\mathrm{C}$ 70.59, H 8.23, N 13.67, O 7.92.

Bis-urea grafted PDMS (14). The content of amine functions of PDMS-g- $\mathrm{NH}_{2}$ was determined by ${ }^{1} \mathrm{H}$ NMR $\left(200 \mathrm{MHz}, \mathrm{CDCl}_{3}\right.$, $22^{\circ} \mathrm{C}$ ). Indeed, the peak at $2.65 \mathrm{ppm}$ corresponds to $2 \mathrm{n}$ protons, whereas the peak at $0.06 \mathrm{ppm}$ corresponds to $6 \mathrm{~m}+3 \mathrm{n}$ protons if the chain ends are neglected (scheme $3 \mathrm{c}$ ). Therefore, the ratio $\mathrm{m} / \mathrm{n}$ can easily be determined.

A solution of the amino-functional PDMS precursor (AMS-162, $35.0 \mathrm{~g}, 19.8 .10^{-3}$ molar equivalent of $\mathrm{NH}_{2}$ functions) in dry THF $(300 \mathrm{~mL})$ was slowly added, at room temperature and under nitrogen, to a stirred solution of (2) (run OC127: heptane, 2,4$\mathrm{TDI} / \mathrm{BuA}$ ratio $\left.=3 / 1-7.66 \mathrm{~g}, 23.7 .10^{-3} \mathrm{~mol}\right)$ in dry THF $(300 \mathrm{~mL})$. After one week, the reaction mixture was concentrated down to about $200 \mathrm{~mL}$ by evaporation of the solvent and precipitated in $2 \mathrm{~L}$ of methanol. The precipitate was then filtered on a $n^{\circ} 2$ fritted funnel, washed thoroughly with methanol and dried under vacuum. $31.5 \mathrm{~g}$ (76\% yield) of an off-white rubbery solid was obtained. ${ }^{1} \mathrm{H}$ NMR $\left(200 \mathrm{MHz}, \mathrm{CDCl}_{3} /\left[\mathrm{D}_{6}\right] \mathrm{DMSO}(85 / 15 \mathrm{v} / \mathrm{v})\right.$, $\left.22^{\circ} \mathrm{C}\right): \delta(\mathrm{ppm})=8.14 / 8.03(\mathrm{~s}, 2 \mathrm{H}, \operatorname{Ar}-\mathrm{N} H), \delta=7.66(\mathrm{~s}, 1 \mathrm{H}, \operatorname{Ar}-H)$, $\delta=7.26(\mathrm{~s}, \quad 1 \mathrm{H}, \quad \operatorname{Ar}-\mathrm{N} H), \quad \delta=7.22(\mathrm{~m}, \quad 3 \mathrm{H}, \quad \operatorname{Ar}-H), \quad \delta=6.97(\mathrm{~d}$, $\left.{ }^{3} \mathrm{~J}(\mathrm{H}, \mathrm{H})=8 \mathrm{~Hz}, 2 \mathrm{H}, \operatorname{Ar}-H\right), \delta=6.90\left(\mathrm{~d},{ }^{3} \mathrm{~J}(\mathrm{H}, \mathrm{H})=8 \mathrm{~Hz}, 1 \mathrm{H}, \operatorname{Ar}-H\right)$, $\delta=6.10\left(\mathrm{t}, 1 \mathrm{H}, \mathrm{CH}_{2}-\mathrm{NH}\right), \delta=3.08\left(\mathrm{~m}, 2 \mathrm{H}, \mathrm{N}-\mathrm{CH}_{2}\right), \delta=2.46(\mathrm{t}, 2 \mathrm{H}$, $\left.\mathrm{Ar}-\mathrm{CH}_{2}\right), \quad \delta=2.08\left(\mathrm{~s}, 3 \mathrm{H}, \mathrm{Ar}-\mathrm{CH}_{3}\right), \delta=1.49\left(\mathrm{~m}, 4 \mathrm{H}, \mathrm{CH}_{2}-\mathrm{CH}_{2}\right.$ $\left.\mathrm{CH}_{2} / \mathrm{Ar}-\mathrm{CH}_{2}-\mathrm{CH}_{2}\right), \delta=1.24\left(\mathrm{~m}, 2 \mathrm{H}, \mathrm{Ar}-\mathrm{CH}_{2}-\mathrm{CH}_{2}-\mathrm{CH}_{2}\right), \delta=0.84(\mathrm{t}$, $\left.{ }^{3} \mathrm{~J}(\mathrm{H}, \mathrm{H})=7 \mathrm{~Hz}, 3 \mathrm{H}, \mathrm{CH}_{3}\right), \delta=0.48\left(\mathrm{~m}, 2 \mathrm{H}, \mathrm{Si}-\mathrm{CH}_{2}\right), \delta=0.01(\mathrm{~s}, 139 \mathrm{H}$, $\left.\mathrm{Si}-\mathrm{CH}_{3}\right) ; \quad \operatorname{IR}(\mathrm{KBr}): \quad v=3318 \mathrm{~cm}^{-1}(\mathrm{~N}-\mathrm{H}), \quad v=1640 \mathrm{~cm}^{-1}(\mathrm{C}=\mathrm{O})$; elemental analysis calcd (\%): C 38.9, H 7.9, N 2.7; found: C 38.53, H 7.92, N 2.72.

PDMS-spaced tetra-ureas $(12,13)$ and other bis-urea grafted PDMS (15). They were synthesized and purified in the same way as (14).

(12) Molar ratio (2) $/$ diamine $=4.4($ Yield $=54 \%),{ }^{1} \mathrm{H}$ NMR $(200$ $\left.\mathrm{MHz}, \quad \mathrm{CDCl}_{3} /\left[\mathrm{D}_{6}\right] \mathrm{DMSO} \quad(85 / 15 \quad \mathrm{v} / \mathrm{v}), \quad 22^{\circ} \mathrm{C}\right)$ : $\delta(\mathrm{ppm})=8.09 / 7.99(\mathrm{~s}, 2 \mathrm{H}, \operatorname{Ar}-\mathrm{N} H), \delta=7.63\left(\mathrm{~d},{ }^{4} \mathrm{~J}(\mathrm{H}, \mathrm{H})=2 \mathrm{~Hz}, 1 \mathrm{H}\right.$, $\operatorname{Ar}-H), \delta=7.26(\mathrm{~s}, 1 \mathrm{H}, \quad \operatorname{Ar}-\mathrm{N} H), \delta=7.22 / 7.14(\mathrm{~m}, 3 \mathrm{H}, \operatorname{Ar}-H)$, $\delta=6.97\left(\mathrm{~d},{ }^{3} \mathrm{~J}(\mathrm{H}, \mathrm{H})=8 \mathrm{~Hz}, 2 \mathrm{H}, \mathrm{Ar}-H\right), \delta=6.90\left(\mathrm{~d},{ }^{3} \mathrm{~J}(\mathrm{H}, \mathrm{H})=8 \mathrm{~Hz}, 1 \mathrm{H}\right.$, $\operatorname{Ar}-H), \delta=6.05\left(\mathrm{t},{ }^{3} \mathrm{~J}(\mathrm{H}, \mathrm{H})=6 \mathrm{~Hz}, 1 \mathrm{H}, \mathrm{CH}_{2}-\mathrm{NH}\right), \delta=3.10(\mathrm{~m}, 2 \mathrm{H}, \mathrm{N}-$ $\left.\mathrm{CH}_{2}\right), \delta=2.46\left(\mathrm{t},{ }^{3} \mathrm{~J}(\mathrm{H}, \mathrm{H})=7 \mathrm{~Hz}, 2 \mathrm{H}, \mathrm{Ar}-\mathrm{CH}_{2}\right), \delta=2.07(\mathrm{~s}, 3 \mathrm{H}, \mathrm{Ar}-$ $\left.\mathrm{CH}_{3}\right), \delta=1.48\left(\mathrm{~m}, 4 \mathrm{H}, \mathrm{CH}_{2}-\mathrm{CH}_{2}-\mathrm{CH}_{2} / \mathrm{Ar}-\mathrm{CH}_{2}-\mathrm{CH}_{2}\right), \delta=1.26(\mathrm{~m}$, $\left.2 \mathrm{H}, \quad \mathrm{Ar}-\mathrm{CH}_{2}-\mathrm{CH}_{2}-\mathrm{CH}_{2}\right), \quad \delta=0.84\left(\mathrm{t},{ }^{3} \mathrm{~J}(\mathrm{H}, \mathrm{H})=7 \mathrm{~Hz}, \quad 3 \mathrm{H}, \quad \mathrm{CH}_{3}\right)$, $\delta=0.49\left(\mathrm{~m}, 2 \mathrm{H}, \mathrm{Si}-\mathrm{CH}_{2}\right), \delta=0.00\left(\mathrm{~s}, 146 \mathrm{H}, \mathrm{Si}-\mathrm{CH}_{3}\right) ; \mathrm{IR}(\mathrm{KBr})$ : $v=3304 \mathrm{~cm}^{-1}(\mathrm{~N}-\mathrm{H}), \mathrm{v}=1638 \mathrm{~cm}^{-1}(\mathrm{C}=\mathrm{O})$; elemental analysis calcd (\%): C 38.5, H 7.9, N 2.6; found: C 39.11, H 8.14, N 2.73.

(13) Molar ratio (2)/diamine $=6.6($ Yield $=86 \%),{ }^{1} \mathrm{H}$ NMR $(200$ $\left.\mathrm{MHz}, \quad \mathrm{CDCl}_{3} /\left[\mathrm{D}_{6}\right] \mathrm{DMSO} \quad(85 / 15 \quad \mathrm{v} / \mathrm{v}), \quad 22^{\circ} \mathrm{C}\right)$ : $\delta(\mathrm{ppm})=8.07 / 7.94(\mathrm{~s}, 2 \mathrm{H}, \operatorname{Ar}-\mathrm{N} H), \delta=7.62\left(\mathrm{~d},{ }^{4} \mathrm{~J}(\mathrm{H}, \mathrm{H})=2 \mathrm{~Hz}, 1 \mathrm{H}\right.$, $\operatorname{Ar}-H), \delta=7.35(\mathrm{~s}, \quad 1 \mathrm{H}, \quad \operatorname{Ar}-\mathrm{N} H), \delta=7.27 / 6.97(\mathrm{~m}, 6 \mathrm{H}, \operatorname{Ar}-H)$, $\delta=5.92\left(\mathrm{t},{ }^{3} \mathrm{~J}(\mathrm{H}, \mathrm{H})=6 \mathrm{~Hz}, 1 \mathrm{H}, \mathrm{CH}_{2}-\mathrm{NH}\right), \delta=3.09\left(\mathrm{~m}, 2 \mathrm{H}, \mathrm{N}-\mathrm{CH}_{2}\right)$, $\delta=2.45\left(\mathrm{t}, 2 \mathrm{H}, \mathrm{Ar}-\mathrm{CH}_{2}\right), \delta=2.09\left(\mathrm{~s}, 3 \mathrm{H}, \mathrm{Ar}-\mathrm{CH}_{3}\right), \delta=1.47(\mathrm{~m}, 4 \mathrm{H}$, $\left.\mathrm{CH}_{2}-\mathrm{CH}_{2}-\mathrm{CH}_{2} / \mathrm{Ar}-\mathrm{CH}_{2}-\mathrm{CH}_{2}\right), \delta=1.25\left(\mathrm{~m}, 2 \mathrm{H}, \mathrm{Ar}-\mathrm{CH}_{2}-\mathrm{CH}_{2}-\mathrm{CH}_{2}\right)$, $\delta=0.82\left(\mathrm{t},{ }^{3} \mathrm{~J}(\mathrm{H}, \mathrm{H})=7 \mathrm{~Hz}, 3 \mathrm{H}, \mathrm{CH}\right), \delta=0.48\left(\mathrm{~m}, 2 \mathrm{H}, \mathrm{Si}-\mathrm{CH}_{2}\right), \delta=$ $0.01\left(\mathrm{~s}, 1160 \mathrm{H}, \mathrm{Si}-\mathrm{CH}_{3}\right) ; \mathrm{IR}(\mathrm{KBr}): v=3303 \mathrm{~cm}^{-1}(\mathrm{~N}-\mathrm{H}), v=1638 \mathrm{~cm}^{-}$ ${ }^{1}(\mathrm{C}=\mathrm{O})$; elemental analysis calcd (\%): C 33.3, H 8.1, N 0.4; found: C $33.28, \mathrm{H} 8.15, \mathrm{~N} 0.43$.

(15) Molar ratio (2)/amine $=1.2($ Yield $=69 \%),{ }^{1} \mathrm{H}$ NMR $(200$ $\left.\mathrm{MHz}, \quad \mathrm{CDCl}_{3} /\left[\mathrm{D}_{6}\right] \mathrm{DMSO} \quad(85 / 15 \quad \mathrm{v} / \mathrm{v}), \quad 22^{\circ} \mathrm{C}\right)$ : $\delta(\mathrm{ppm})=7.39 / 7.24(\mathrm{~m}, 8 \mathrm{H}, \mathrm{Ar}-H / \mathrm{Ar}-\mathrm{N} H), \delta=6.89\left(\mathrm{~d},{ }^{3} \mathrm{~J}(\mathrm{H}, \mathrm{H})=8 \mathrm{~Hz}\right.$, $1 \mathrm{H}, \operatorname{Ar}-H), \delta=6.32(\mathrm{~s}, 1 \mathrm{H}, \operatorname{Ar}-\mathrm{N} H), \delta=6.10\left(\mathrm{t}, 1 \mathrm{H}, \mathrm{CH}_{2}-\mathrm{N} H\right)$, $\delta=3.22\left(\mathrm{~m}, 3 \mathrm{H}, \mathrm{N}-\mathrm{CH}_{3}\right), \delta=3.04\left(\mathrm{~m}, 2 \mathrm{H}, \mathrm{N}-\mathrm{CH}_{2}\right), \delta=2.18(\mathrm{~s}, 3 \mathrm{H}$, $\left.\mathrm{Ar}-\mathrm{CH}_{3}\right), \delta=1.43\left(\mathrm{~m}, 2 \mathrm{H}, \mathrm{CH}_{2}-\mathrm{CH}_{2}-\mathrm{CH}_{2}\right), \delta=0.44\left(\mathrm{~m}, 2 \mathrm{H}, \mathrm{Si}-\mathrm{CH}_{2}\right)$, $\delta=0.00\left(\mathrm{~s}, 141 \mathrm{H}, \mathrm{Si}-\mathrm{CH}_{3}\right) ; \mathrm{IR}(\mathrm{KBr}): v=3429 / 3346 / 3290 \mathrm{~cm}^{-1}(\mathrm{~N}-$ $\mathrm{H}), v=1637 \mathrm{~cm}^{-1}(\mathrm{C}=\mathrm{O})$; elemental analysis calcd (\%): $\mathrm{C} 37.7, \mathrm{H}$ 7.8, N 2.7; found: C 37.33, H 7.92, N 2.56.

Symmetrical bis-urea (16). This symmetrical bis-urea could have been obtained directly by reacting 2,4-TDI with two equivalents of $\mathrm{BuA}$; but the synthesis described here consists in reacting (2) with $\mathrm{BuA}$. A solution of $\mathrm{BuA}\left(0.22 \mathrm{~mL}, 1.4 .10^{-3} \mathrm{~mol}\right)$ in dry THF $(10 \mathrm{~mL})$ was added in $10 \mathrm{~min}$, at room temperature and under nitrogen, to a stirred solution of (2) (run OC072: dichloromethane, $\left.2,4-\mathrm{TDI} / \mathrm{BuA}=5 / 1-0.220 \mathrm{~g}, 6.8 .10^{-4} \mathrm{~mol}\right)$ in dry THF $(20 \mathrm{~mL}) . \mathrm{A}$ white precipitate appeared more than $3 \mathrm{~h}$ after the addition of the amine. After 11 days at room temperature, the reaction was complete according to the absence of isocyanate functions $\left(2270 \mathrm{~cm}^{-1}\right.$ in FTIR spectroscopy). The precipitate was filtered on a fritted funnel, rinsed three times with small quantities of THF, and dried under vacuum to afford a white solid (70\%). It was not recrystallised because of its poor solubility. ${ }^{1} \mathrm{H}$ NMR $(200 \mathrm{MHz}$, $\left.\left[\mathrm{D}_{6}\right] \mathrm{DMSO}, 22^{\circ} \mathrm{C}\right): \delta(\mathrm{ppm})=8,96 / 8.61 / 8.42(\mathrm{~s}, \quad 3 \mathrm{H}, \quad \operatorname{Ar}-\mathrm{N} H)$, $\delta=7.92\left(\mathrm{~d},{ }^{4} \mathrm{~J}(\mathrm{H}, \mathrm{H})=2 \mathrm{~Hz}, 1 \mathrm{H}, \operatorname{Ar}-H\right), \delta=7.84(\mathrm{~s}, 1 \mathrm{H}, \operatorname{Ar}-\mathrm{N} H)$, $\delta=7.37 / 7.32\left(\mathrm{~d}, \quad{ }^{3} \mathrm{~J}(\mathrm{H}, \mathrm{H})=8 \mathrm{~Hz}, \quad 4 \mathrm{H}, \quad \operatorname{Ar}-H\right), \quad \delta=7.19(\mathrm{dd}$, $\left.{ }^{3} \mathrm{~J}(\mathrm{H}, \mathrm{H})=8 \mathrm{~Hz}, \quad{ }^{4} \mathrm{~J}(\mathrm{H}, \mathrm{H})=2 \mathrm{~Hz}, \quad 1 \mathrm{H}, \quad \operatorname{Ar}-H\right), \quad \delta=7.09 / 7.07(\mathrm{~d}$, 
$\left.{ }^{3} \mathrm{~J}(\mathrm{H}, \mathrm{H})=8 \mathrm{~Hz}, 4 \mathrm{H}, \mathrm{Ar}-H\right), \delta=7.03(\mathrm{~m}, 1 \mathrm{H}, \mathrm{Ar}-H), \delta=2.5(\mathrm{t}, 4 \mathrm{H}, \mathrm{Ar}-$ $\left.\mathrm{CH}_{2}\right), \delta=2.17\left(\mathrm{~s}, 3 \mathrm{H}, \mathrm{Ar}-\mathrm{CH}_{3}\right), \delta=1.52\left(\mathrm{~m}, 4 \mathrm{H}, \mathrm{Ar}-\mathrm{CH}_{2}-\mathrm{CH}_{2}\right)$, $\delta=1.29\left(\mathrm{~m}, 4 \mathrm{H}, \mathrm{Ar}-\mathrm{CH}_{2}-\mathrm{CH}_{2}-\mathrm{CH}_{2}\right), \delta=0.89\left(\mathrm{t},{ }^{3} \mathrm{~J}(\mathrm{H}, \mathrm{H})=7 \mathrm{~Hz}, 6 \mathrm{H}\right.$, $\left.\mathrm{CH}_{3}\right)$.

Acknowledgement. Sylvaine Ragout and Matthieu Jalabert are thanked for their technical assistance. Nexans company is acknowledged for financial support.

\section{References}

$\dagger \quad$ The word symmetrical refers to $\mathrm{R}^{1}$ and $\mathrm{R}^{2}$ substituants and neglects the presence of the methyl group on the central ring.

$\S$ In dichloromethane, the elimination of 2,4-TDI is more difficult because of the viscosity of the reaction mixture when 1.5 equivalents are used: a small amount of (1) is formed in the second step of this run. With a larger excess of 2,4-TDI though, more solvent is used and the filtration eliminates all the remaining 2,4-TDI.

1 J.-M. Lehn. Supramolecular Chemistry: Concepts and Perspectives, VCH, 1995.

2 (a) A. Ciferri. Supramolecular polymers: New York, 2000; (b) A. Ciferri, J. Macromol. Sci., Polym. Rev., 2003, C43(2), 271.

3 L. Brunsveld, B. B. Folmer, E. W. Meijer and R. P. Sijbesma, Chem. Rev., 2001, 101(12), 4071.

4 N. Zimmerman, J. S. Moore and S. C. Zimmerman, Chem. Ind., 1998 , 604.

5 F. Lortie, S. Boileau, L. Bouteiller, C. Chassenieux, B. Demé, G. Ducouret, M. Jalabert, F. Lauprêtre and P. Terech, Langmuir, 2002, 18,7218 .

6 V. Simic, L. Bouteiller and M. Jalabert, J. Am. Chem. Soc., 2003, 125,13148 .

7 J. H. Saunders and R. J. Slocombe, Chem. Rev., 1948, 43, 203.

8 R. G. Arnold, J. A. Nelson and J. J. Verbanc, Chem. Rev., 1957, 57, 47.

9 B. Grepinet, F. Pla, P. Hobbes, P. Swaels and T. Monge, J. Appl. Polym. Sci., 2000, 75, 705.

10 C. F. Bartelink, M. De Pooter, H. J. M. Grünbauer, U. Beginn and M. Möller, J. Polym. Sci. Part A: Polym. Chem., 2000, 38(14), 2555.

11 C. W. Carpenter, T. G. Savino and A. L. Steinmetz, EP 465 805, 2000.

12 O. Colombani, PhD Thesis, Université Paris VI (France), 2003.

13 O. Colombani, L. Bouteiller, C. Barioz, J. Bonetti-Riffaud and L. Fompérie, Polymer Preprints, 2003, 44(1), 620.

14 S. Boileau, L. Bouteiller, F. Lauprêtre and F. Lortie, New J. Chem., 2000, 24, 845 .

15 T. V. Kozlova and V. V. Zharkov, Zh. Prikl. Spektrosk., 1981, 35(2), 303.

16 H. Lee, J. Park, C. Yoon and Y. S. Choi, Bull. Korean Chem. Soc., 1988, 19(1), 110.

17 L. de Lucca Freitas, C. Auschra, V. Abetz and R. Stadler, Colloid Polym. Sci., 1991, 269, 566.

18 R. Stadler, Macromolecules, 1988, 21, 121.

19 O. Colombani, C. Barioz, L. Bouteiller, C. Chanéac, G. Ducouret, L. Fompérie, F. Lortie and H. Montès, to be published. 
Table 1 Evaluation of the selectivity of the synthesis of (2)

\begin{tabular}{|c|c|c|c|c|c|c|c|c|}
\hline Run & Solvent & $\frac{2,4-\mathrm{TDI}}{\mathrm{BuA}}$ & $\begin{array}{l}\text { Yield } \\
(\%)^{a}\end{array}$ & $\begin{array}{l}16 \\
(\%)^{b}\end{array}$ & $\begin{array}{l}5 \mathrm{~b} \\
(\%)^{b}\end{array}$ & $\begin{array}{l}5 \mathrm{a} \\
(\%)^{b}\end{array}$ & $\begin{array}{l}1 \\
(\%)^{b}\end{array}$ & $5 \mathrm{a} / 5 \mathrm{~b}$ \\
\hline OC103 & heptane & 1 & 92 & 6 & 11 & 83 & $<1$ & 8 \\
\hline OC 105 & heptane & 1,5 & 94 & 1 & 15 & 83 & 1 & 6 \\
\hline OC116 & heptane & 3 & 95 & $<1$ & 14 & 86 & $<1$ & 6 \\
\hline OC127 & heptane & 3 & 92 & $<1$ & 8 & 92 & $<1$ & 12 \\
\hline OC084 & heptane & 5 & 97 & $<1$ & 11 & 89 & $<1$ & 8 \\
\hline OC134 & $\mathrm{CH} 2 \mathrm{Cl} 2$ & & 67 & 14 & 2 & 84 & $<1$ & 35 \\
\hline OC135 & $\mathrm{CH} 2 \mathrm{Cl} 2$ & 1,5 & 70 & 5 & 3 & 90 & 2 & 26 \\
\hline OC072 & $\mathrm{CH} 2 \mathrm{Cl} 2$ & & 73 & $<1$ & $<1$ & $>97$ & $<1$ & $>97$ \\
\hline OC108 & THF & 1 & n.a. ${ }^{c}$ & 5 & 19 & 59 & 17 & 3 \\
\hline OC109 & THF & 1,5 & n.a. ${ }^{c}$ & 1 & 14 & 48 & 37 & 3 \\
\hline
\end{tabular}

${ }^{a}$ Product yield for the first step (obtained weight divided by expected weight of (2) if the reaction is fully selective).

${ }^{b}$ The amounts of (16), (5b), (5a) and (1) at the end of the second step correspond to those of (16), (2b), (2a) and 2,4-TDI respectively, at the end of the first step.

${ }^{c}$ Not available because the first step was not purified.

Table 2 Solubility tests at room temperature

\begin{tabular}{|c|c|c|c|c|c|}
\hline Name & Compound & Heptane & Toluene & Chloroform & THF \\
\hline $5 \mathbf{a}$ & bis-urea & $\mathrm{I}(10)$ & G(10) & $\mathbf{S}$ & $\mathbf{S}$ \\
\hline $6 \mathbf{a}$ & bis-urea & $\mathrm{I}(2)$ & $\mathrm{I}(2)$ & $\mathrm{I}(2)$ & $\mathrm{I}(2)$ \\
\hline 7 & bis-urea & $\mathrm{I}(10)$ & $\mathbf{S}$ & $\mathbf{S}$ & $\mathbf{S}$ \\
\hline 8 & aliphatic tetra-urea & $\mathrm{I}(5)$ & $\mathrm{I}(5)$ & $\mathrm{I}(5)$ & $\mathrm{I}(5)$ \\
\hline 9 & aliphatic tetra-urea & $\mathrm{I}(10)$ & $\mathrm{I}(10)$ & $\mathrm{I}(10)$ & $\mathrm{I}(10)$ \\
\hline 10 & aliphatic tetra-urea & $\mathrm{I}(1)$ & $\mathrm{I}(1)$ & $\mathrm{I}(1)$ & $\mathrm{I}(1)$ \\
\hline 11 & aliphatic tetra-urea & $\mathrm{I}(1)$ & $\mathrm{I}(1)$ & $\mathrm{I}(1)$ & $\mathrm{I}(1)$ \\
\hline 12 & PDMS tetra-urea & $\mathrm{I}(10)$ & SW & SW & $\mathbf{S}$ \\
\hline 13 & PDMS tetra-urea & $\mathbf{S} / \mathbf{G}(\mathbf{5 0})$ & $\mathbf{S} / \mathbf{G ( 5 0 )}$ & $\mathbf{S}$ & $\mathbf{S}$ \\
\hline 14 & PDMS-g-bis-urea & SW & SW & SW & $\mathbf{S}$ \\
\hline 15 & PDMS-g-bis-urea & $\mathbf{S}$ & $\mathbf{S}$ & $\mathbf{S}$ & $\mathbf{S}$ \\
\hline 16 & bis-urea & $\mathrm{I}(1)$ & $\mathrm{I}(1)$ & $\mathrm{I}(1)$ & $\mathrm{I}(1)$ \\
\hline
\end{tabular}

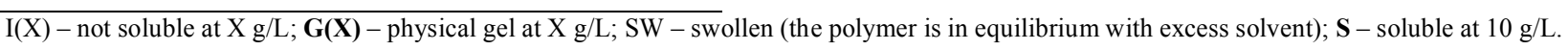

$\underline{\text { Table } 3 \text { Association constants }\left(\mathrm{L} \mathrm{mol}^{-1}\right) \text { in chloroform determined by curve fitting }}{ }^{6}$

\begin{tabular}{lllll}
\hline name & $\mathrm{K}_{2}$ & $\mathrm{~K}$ & $\mathrm{~K} / \mathrm{K}_{2}$ & $\mathrm{~K}{ }^{2} / \mathrm{K}_{2}$ \\
\hline $\mathbf{5 a}$ & $110+/-507400+/-500$ & $70+/-45$ & $5,1 \mathrm{E}+05+/-3,7 \mathrm{E}+05$ \\
$\mathbf{1 3}$ & $470+/-20$ & $2200+/-300$ & $4+/-1$ & $9,9 \mathrm{E}+03+/-2,2 \mathrm{E}+03$ \\
$\mathbf{1}$ & $21+/-3$ & $1400+/-200$ & $70+/-20$ & $1,0 \mathrm{E}+05+/-0,5 \mathrm{E}+05$ \\
mono-urea & $2+/-1$ & $8+/-1$ & $4+/-2$ & $36+/-10$ \\
\hline
\end{tabular}


(a)

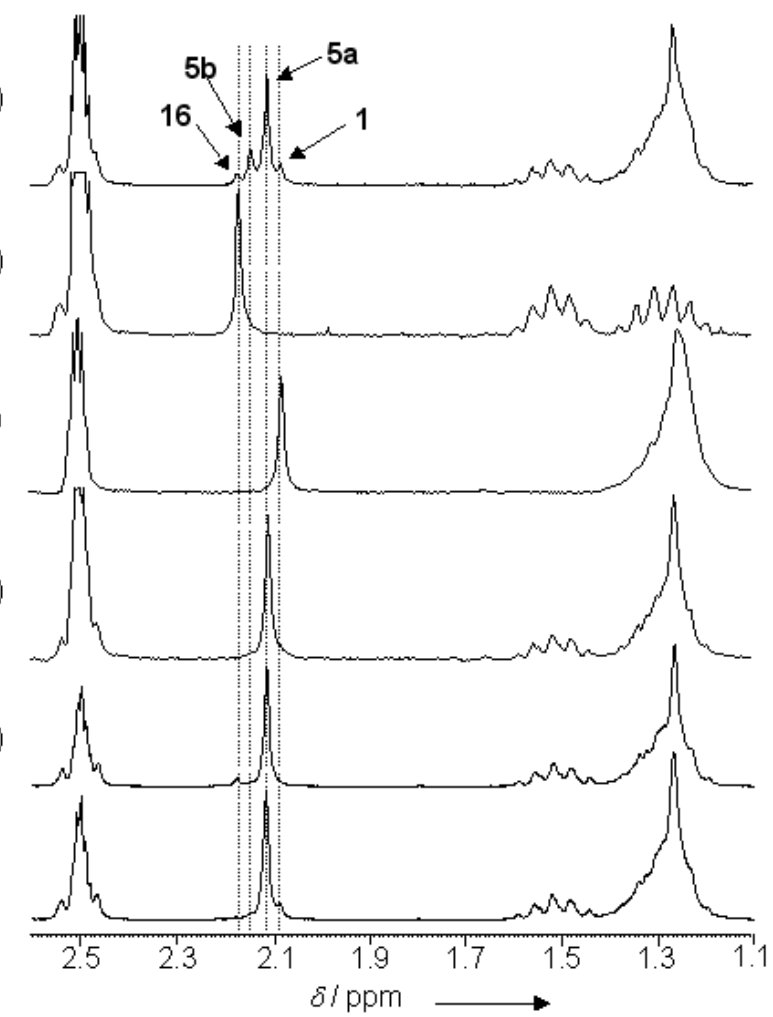

Fig. $1{ }^{1} \mathrm{H}$ NMR spectra of the possible products of the reaction described in scheme 4. Unselective synthesis (OC108) (a); symmetrical bis-ureas (16) (b) and (1) (c); non-symmetrical bis-urea (5a) (d); intentional mixtures of (5a) $+5 \%$ of (16) (e), and (5a) $+5 \%$ of (1) (f). The peak at ca. 2.1 . ppm corresponds to the methyl group on the aromatic ring.

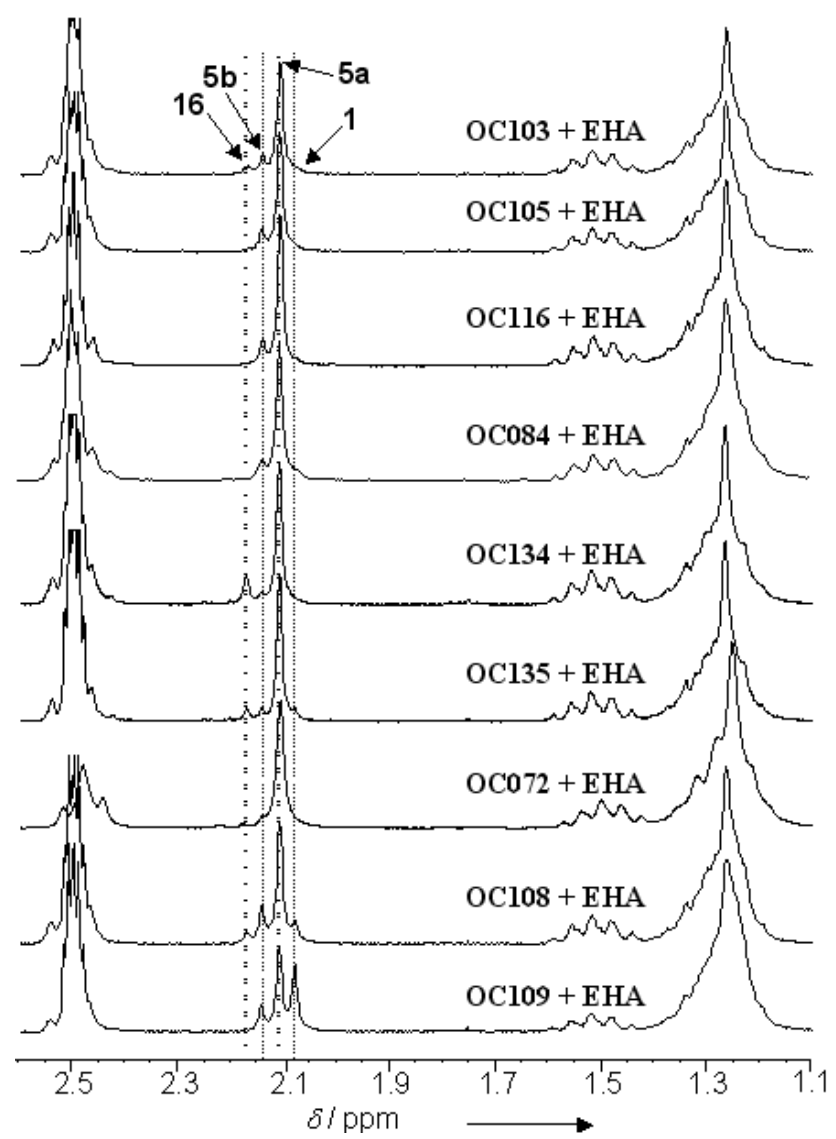

Fig. $2{ }^{1} \mathrm{H}$ NMR spectra of the crude product of the second step (scheme 4), for different reaction conditions of the first step. See table 1 for the experimental conditions. 


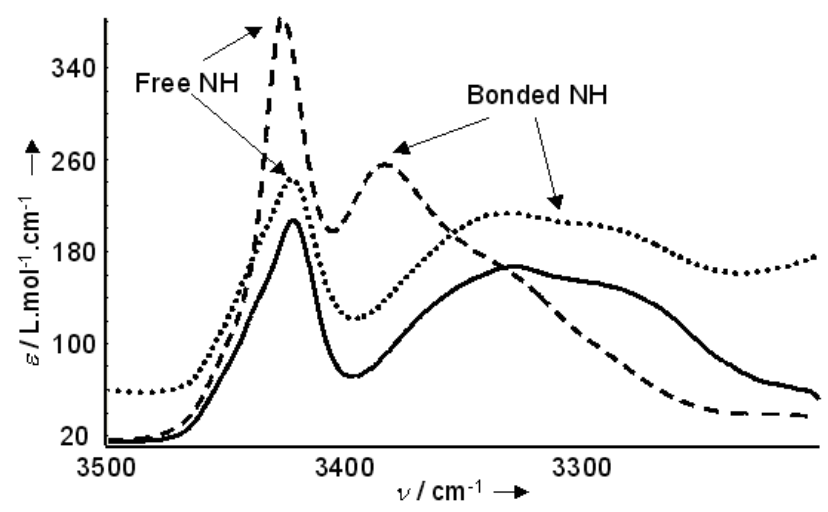

Fig. 3 FTIR spectra of (7) at $4.510^{-2} \mathrm{~mol} / \mathrm{L} \mathrm{(--),} \mathrm{(13)} \mathrm{at} 1.010^{-3} \mathrm{~mol} / \mathrm{L}(\ldots)$, and (5a) at $2.510^{-4} \mathrm{~mol} / \mathrm{L}(-)$ in $\mathrm{CDCl}_{3}$. These solutions exhibit a free $\mathrm{NH}$ fraction of $\sim 60 \%$.

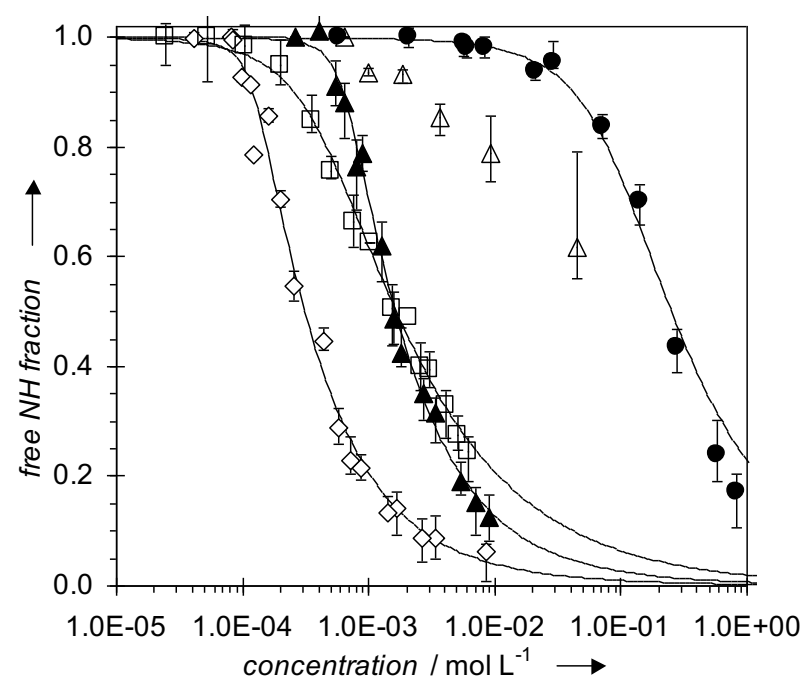

Fig. 4 Evolution of the fraction of free NH functions versus bis-urea concentration in chloroform. Full curves are obtained by curve fitting with the model described in scheme 5. See schemes $1,3 \mathrm{a}$ and $3 \mathrm{~b}$ for molecular structures. 5a $\left.\left({ }^{-}\right\rangle_{-}^{-}\right), \mathbf{1}\left(-\mathbf{\Delta}^{-}\right), \mathbf{1 3}\left(-\square^{-}\right), 7(\triangle)$, N-2-ethylhexyl,N'-2-methylphenylurea $(\bullet)$.

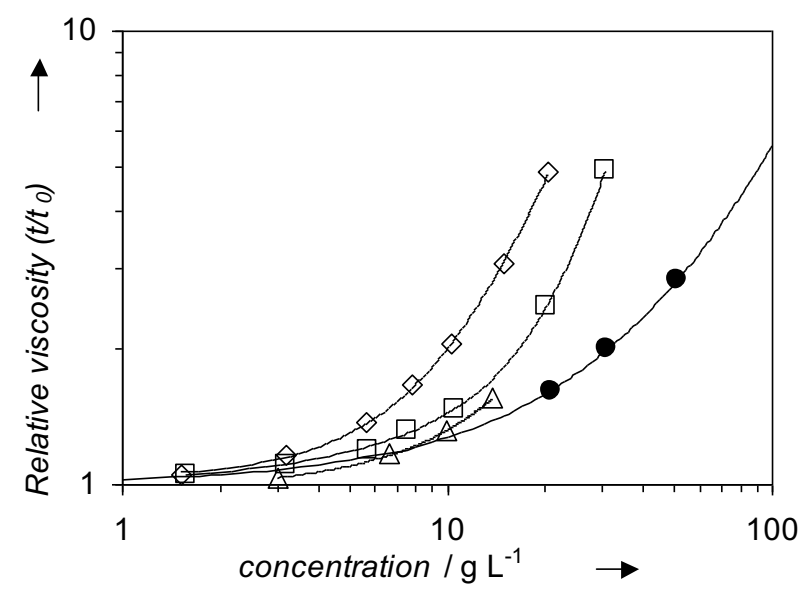

Fig. 5 Relative viscosity of chloroform solutions of $\mathbf{5 a}(-\diamond-), \mathbf{1 3}(-\square-), \mathbf{1}(-\triangle-)$, and of the amino-functional precursor of $\mathbf{1 3}(-\bullet-)$ versus concentration of bis-ureas at $25 \pm 0,1^{\circ} \mathrm{C}$. 


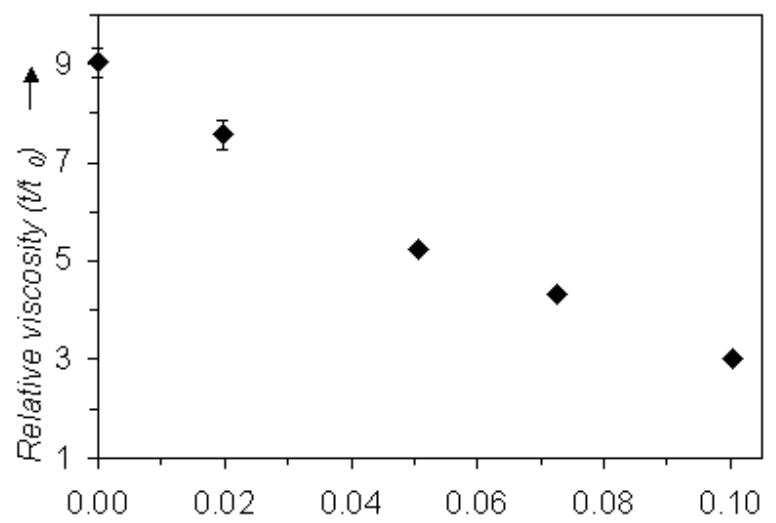

Weight fraction of (7) in the (1)+(7) mixture

Fig. 6 Relative viscosity of a (7)+(1) solution in toluene versus weight fraction of (7), at a constant total weight concentration of $0.5 \mathrm{mg} \mathrm{g}^{-1}$ and at $25 \pm 0.1^{\circ} \mathrm{C}$.<smiles>[R]NC(=O)Nc1cc(N([2H])C(=O)N[R])ccc1C</smiles>

rigid 2,4-toluene spacer<smiles></smiles>

Scheme. 1 General formula of bis-ureas.<smiles>[R]NPC(C)C</smiles><smiles>[R][C-][Si]</smiles><smiles>[R]C=[V]</smiles>

$\mathrm{R}^{1}=\mathrm{R}_{\mathrm{C}}^{3}=\mathrm{CH}_{3}$

Scheme. 2 Mono-isocyanate/mono-ureas.<smiles>[R]N([R])C(=O)Nc1ccc(C)c([N+](=O)[O-])c1</smiles><smiles>[R]N([R])C(=O)Nc1cc([N+](=O)[O-])ccc1C</smiles>

2a

$2 \mathrm{~b}=$ 2

$3 a$

$4 a$

$4 \mathrm{~b}=4$ 
<smiles>[R]N([R])C(=O)Nc1cccc([N+](=O)[O-])c1</smiles>

$\mathrm{R}^{1}=\mathrm{R}^{3}=\mathrm{H}$

2

$\mathrm{R}^{1}=$

3

$\mathrm{R}^{1}=\mathrm{R}_{\mathrm{C}}=\mathrm{CH}_{3}$

4

Scheme. 3a Non-symmetrical bis-ureas.

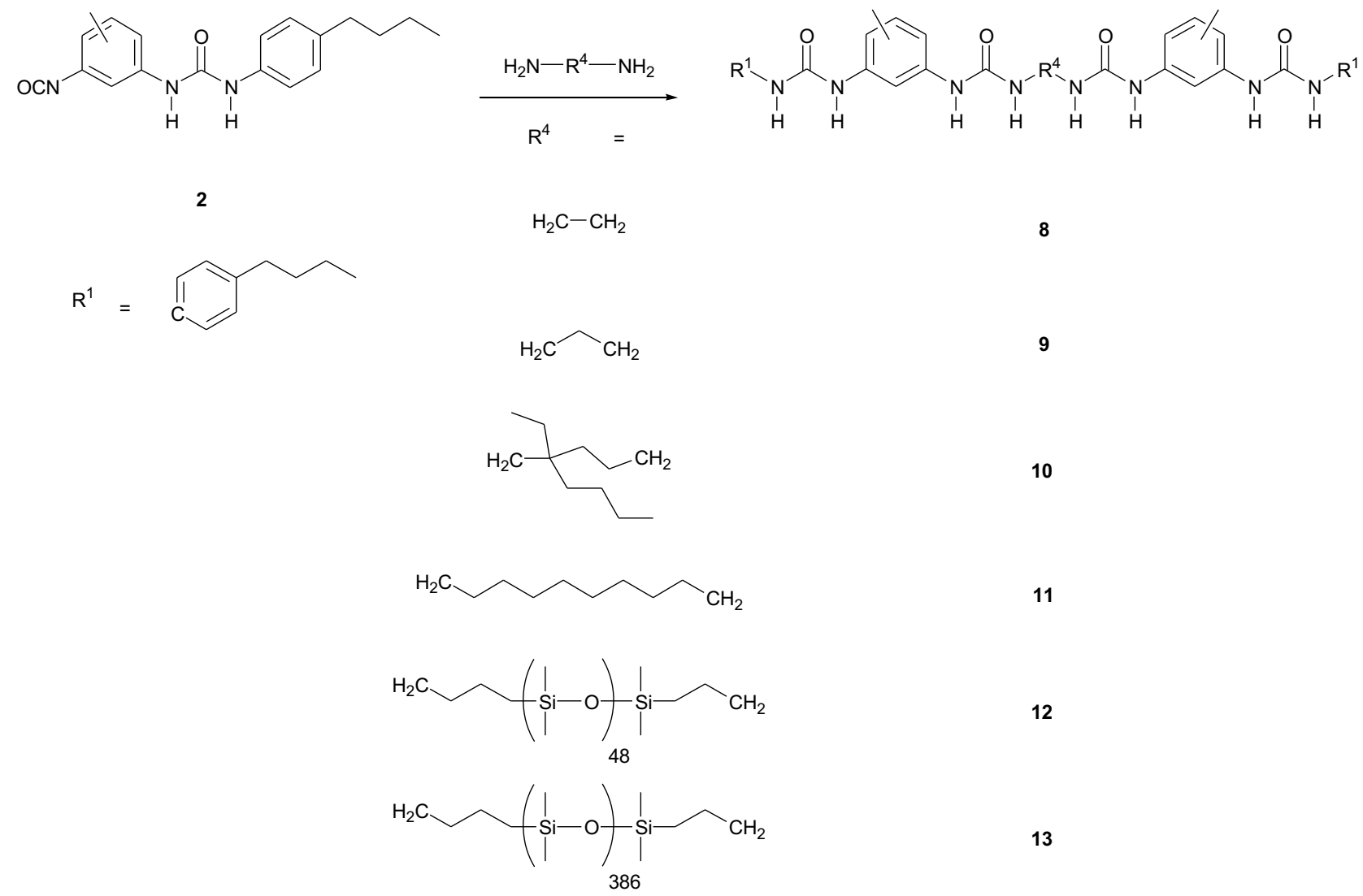

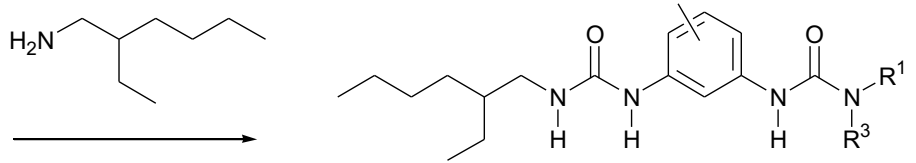

5

6

7 

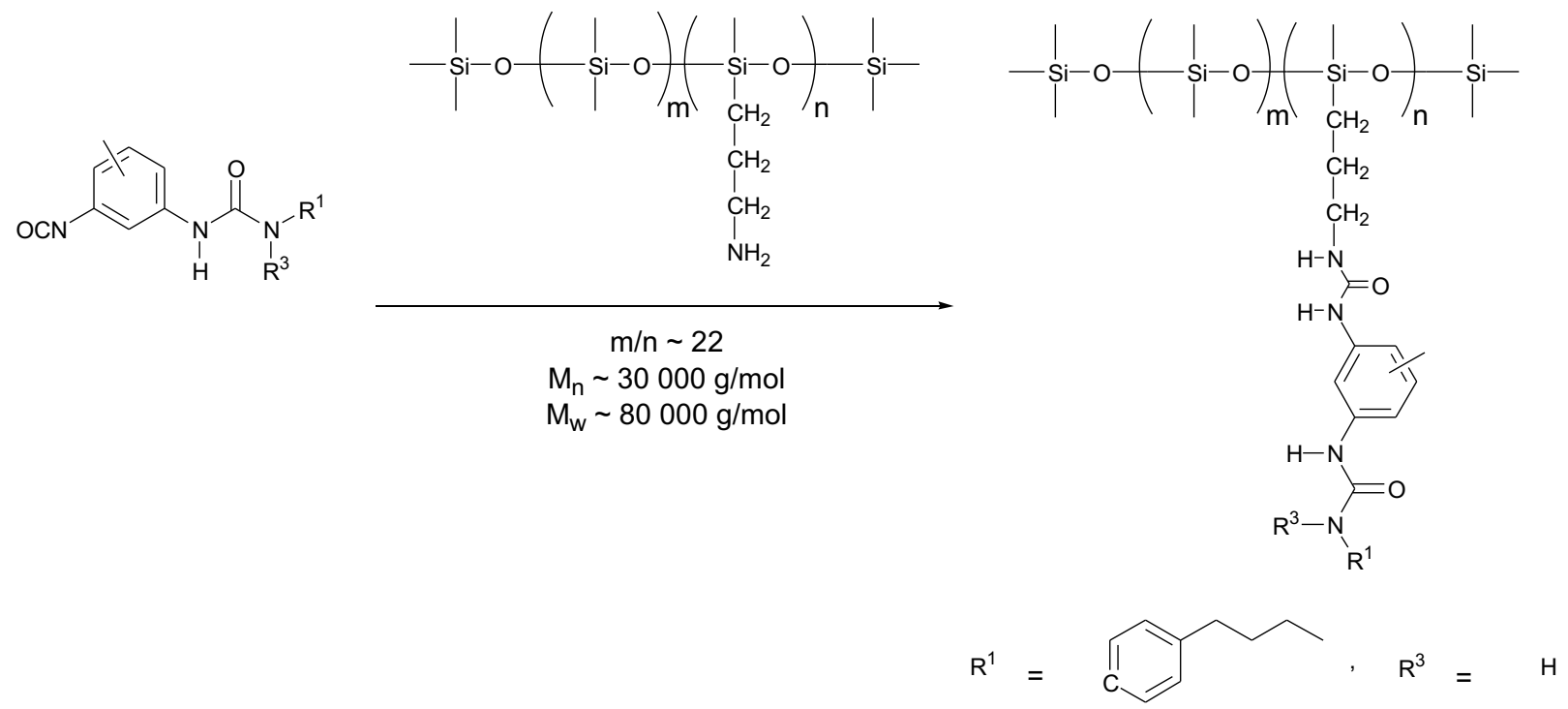

14

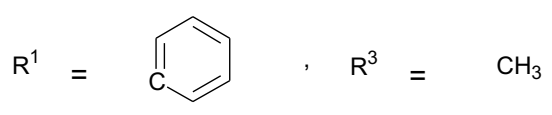

15

Scheme. 3c PDMS grafted bis-ureas.<smiles>[R1]NC(=O)N([TlH])c1ccc(C)c([N+](=O)[O-])c1</smiles>

$2 \mathrm{a}$<smiles>Cc1ccc([N+](=O)[O-])cc1[N+](=O)[O-]</smiles>

2,4-TDI<smiles>Cc1ccc(N=O)cc1N=O</smiles>
1) $H_{2} N-R^{1}$<smiles>[R]NC(=O)Nc1cc([N+](=O)[O-])ccc1C</smiles>

2b<smiles>[R1]NC(=O)Nc1cc(N([Y])C(=O)N[R1])ccc1C</smiles>

16

2) $\mathrm{H}_{2} \mathrm{~N}-\mathrm{R}^{2}$<smiles>[R]NC(=O)Nc1ccc(C)c(NC(=O)N[R])c1</smiles>

$5 a$<smiles>[R]NC(=O)Nc1ccc(C)c(NC(=O)N[R])c1</smiles>

$5 b$<smiles>[R]NC(=O)Nc1ccc(C)c(NC(=O)N[R])c1</smiles><smiles>[R]NC(=O)Nc1ccc(C)c(NC(=O)N[R])c1</smiles><smiles></smiles>

and

$\mathrm{H}_{2} \mathrm{C}$<smiles>C1CCCCCCCC1</smiles>

Scheme. 4 Possible products of the reaction of 2,4-TDI with BuA in a first step and EHA in a second step. 


$$
\begin{array}{ll}
M+M & \stackrel{K_{2}}{\rightleftharpoons} M_{2} \\
M_{n}+M & \stackrel{K}{\rightleftharpoons} M_{n+1} \\
M_{n}+M_{p} & \stackrel{K^{2} / K_{2}}{\rightleftharpoons} M_{n+p}
\end{array}
$$

Equation 1 - Association equilibria of bis-ureas

$M=$ free bis-urea

$M_{n}=n$ associated bis-ureas $-n>1$

$M_{p}=p$ associated bis-ureas $-p>1$

Scheme. 5 Association equilibria of bis-ureas. 